\title{
History of the Munich-Maisach-Fürstenfeldbruck Geomagnetic Observatory
}

\author{
H. C. Soffel \\ Geophysikalisches Observatorium der Universität München, Ludwigshöhe 8, \\ 82256 Fürstenfeldbruck, Germany \\ Correspondence to: H. C. Soffel (soffel@geophysik.uni-muenchen.de)
}

Received: 27 January 2015 - Revised: 31 March 2015 - Accepted: 19 May 2015 - Published: 07 July 2015

\begin{abstract}
The Munich-Maisach-Fürstenfeldbruck Geomagnetic Observatory is one of the observatories with the longest recordings of the geomagnetic field. It started with hourly measurements on 1 August 1840. The founder of the observatory in Munich was Johann von Lamont (1805-1879), the Director of the Royal Bavarian Astronomical Observatory. He had been stimulated to build his own observatory by the initiative of the Göttingen Magnetic Union founded in 1834 by Alexander von Humboldt (1769-1859) and Carl Friedrich Gauss (1777-1855). Before 1840 fewer than five observatories existed; the most prominent ones were those in London and Paris. At the beginning Lamont used equipment delivered by Gauss in Göttingen, but soon started to build instruments of his own design. Among them was a nonmagnetic theodolite which allowed precise geomagnetic measurements to be made also in the field. During the 1850s Lamont carried out geomagnetic surveys and produced geomagnetic maps for Germany and many other European countries. At the end of the nineteenth century accurate geomagnetic measurements in Munich became more and more disturbed by the magnetic stray fields from electric tramways and industry. During this period the quality of the data suffered and the measurements had to be interrupted several times. After a provisional solution in Maisach, a village $25 \mathrm{~km}$ west of Munich, a final solution could be found in the vicinity of the nearby city of Fürstenfeldbruck. Here the measurements started again on 1 January 1939. Since the 1980s the observatory has been part of INTERMAGNET, an organization providing almost real-time geomagnetic data of the highest quality.
\end{abstract}

\section{Introduction}

Geophysical observatories are part of an international network for the acquisition of geophysical data and the surveillance of system Earth. The stations for the observation of the geomagnetic field were the first, dating back to the sixteenth century, when it was recognized that geomagnetic data were of vital importance for the navigation of the ships of seafaring nations. Because the magnetic field changes with time, permanent monitoring was necessary. During the first half of the nineteenth century more geomagnetic observatories were set up in many countries, now mostly for scientific purposes and for a better understanding of the general features of the geomagnetic field and its temporal and regional variations. Later, during the nineteenth and twentieth centuries, other earth science disciplines started their own networks of stations for the observation and monitoring of other phenomena, most importantly earthquakes, meteorology, oceanography, hydrology, geodesy and glaciology.

This paper presents the history of the Munich-MaisachFürstenfeldbruck Geomagnetic Observatory, founded in 1840 in Bogenhausen (now a suburb of Munich) at the site of the Astronomical Observatory of the Bavarian Academy of Sciences on the initiative of Johann (John) Lamont (18051879), then director of this institution. At that time a locality near the village of Bogenhausen was an ideal place for astronomy and later also for geomagnetism. Disturbances from the nearby city of Munich did not impact on this rural environment. However, the situation changed dramatically at the end of the nineteenth century, when Munich became more and more illuminated during night time, electric tramway systems were installed and the industrialization of the city 
expanded more and more, increasingly disturbing astronomical and geomagnetic observations.

From 1923 onwards, occasional geomagnetic observatory work with absolute measurements of the field began near Maisach, a village about $25 \mathrm{~km}$ west of Munich. After 1931, these observations were extended to include temporal variations of the field. However, this site in turn had to be abandoned because of plans for an enlargement of a nearby small airport for military purposes. Fortunately, in 1937, money became available for a completely new observatory near the town of Fürstenfeldbruck, where it remains in operation to this day. Regular measurements of the absolute magnetic field and its temporal variations started on 1 January 1939. The Munich-Maisach-Fürstenfeldbruck observatory is one of the world's oldest geomagnetic observatories and belongs to a small group of stations for which the recording time of the geomagnetic field exceeds 175 years.

\section{Early history}

The Royal Astronomical Observatory of the Bavarian Academy of Sciences, where the Geomagnetic Observatory was later established, was built in the years $1816 / 1817$ near the village of Bogenhausen (now a suburb of Munich) on the eastern banks of the river Isar to replace a much smaller observatory with a simple telescope near the centre of Munich in Haidhausen (Fig. 1). The new observatory was completely surrounded by farmland. At that time, with only a moderate illumination of the city during the night, Bogenhausen was an ideal place for an astronomical observatory. Industrialization had not yet begun and disturbances did not occur. Georg von Soldner (1776-1833, Plate 1a) was its first director. His life and qualities as an astronomer and geodesist have been described by Past (2005). During the first decades of the nineteenth century Munich was famous for the production of high-quality telescopes by Josef von Utzschneider (1763-1840) and Josef von Fraunhofer (1787-1826). A new telescope (diameter of the lens $28.5 \mathrm{~cm}$; focal length $5 \mathrm{~m}$ ) was ordered by Soldner in 1825 and installed in the observatory in 1834. For a few years, Munich had the best telescope in the world.

The successor to Soldner was Johann (von) Lamont (1805-1879, Plate 1b, c). It was he who founded the Geomagnetic Observatory in 1840. He was born as John Lamont on 13 December 1805 in Corriemulzie, a small hamlet near Braemar in the Scottish Highlands (Häfner and Soffel, 2006; Wienert, 1991). His father, who was the forester of the Earl of Fife, died from an accident when John was 11 years old. In 1817 Father Robertson from the Scottish Benedictine Monastery of St. Jakob at Regensburg in Bavaria came to Scotland looking for talented boys to bring them to Bavaria for an education in theology. John passed the examinations and was accepted. He was ready to leave his family and to accompany Robertson, together with another boy, to Regens- burg. However, the talented John was interested in learning not only theology and classical and modern languages, but also in receiving a training in mathematics, natural sciences and mechanics. One of the Scottish priests in Regensburg, Father Benedict Deasson, a prior well trained in these fields, became his teacher. After 1827, John was allowed to spend most of his vacation times at the Royal Bavarian Astronomical Observatory in Bogenhausen. One year later, in 1828, the monastery permitted John to give up further education in theology and to become the Assistant to Soldner in the observatory. In 1830 he graduated with a $\mathrm{PhD}$ in astronomy at the University of Munich. At that time he adopted the name Johann, the German version of John. Due to an illness of Soldner in the early 1830 s, Lamont gradually had to take over most of the duties of the director, and when Soldner died in 1833 the responsibility for the whole observatory rested on his shoulders. In 1835, at the age of 29, Lamont was appointed officially as Director of the Astronomical Observatory; later in this year he also became a member of the Bavarian Academy of Sciences.

\section{Foundation of the geomagnetic observatory in Munich}

Johann von Lamont was a scientist with many talents and interests. More details about Lamont's family background, life and achievements in various disciplines can be taken from Burmeister (1941, 1950), Wienert (1966, 1991), Korschunow (1966), Beblo (1991), Barraclough et al. (1992), Soffel (2005a-d, 2006, 2010), Häfner and Soffel (2006) and Soffel and Häfner (2009). During his initial years as director of the observatory he continued his research in astronomy using the new powerful telescope of Utzschneider and Fraunhofer. Things changed in 1835 , when he came into contact with geomagnetism. The physicist Carl August von Steinheil (1801-1870) from the University of Munich had been asked in January 1836 by Alexander von Humboldt and Carl Friedrich Gauss to participate in a programme to observe temporal variations of the horizontal component of the geomagnetic field along a north-south-directed profile at seven stations between Den Haag (Netherlands) and Catania (Italy). Assisted by Lamont as Director of the Astronomical Observatory, he installed a heavy magnet suspended on a thin fibre in the basement of the observatory in Bogenhausen. The instrument was provided by Gauss. The orientation of the magnet was monitored with hourly readings using a telescope. On 30 January 1836 a small magnetic storm was recorded by all stations and it was observed that the amplitude of the magnetic disturbances decreased with geographic latitude along the profile. This experience fascinated Lamont and encouraged him to start geomagnetic research and to build his own geomagnetic observatory on the site of the Astronomical Observatory, seemingly an ideal place for that purpose. 

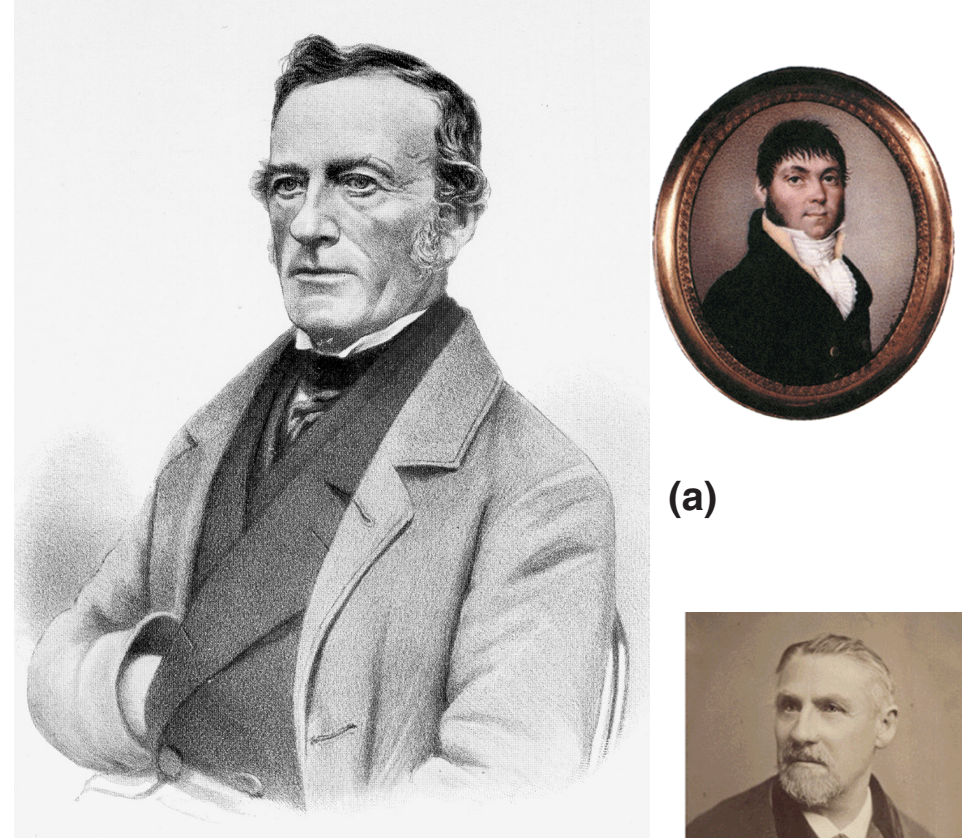

(a)

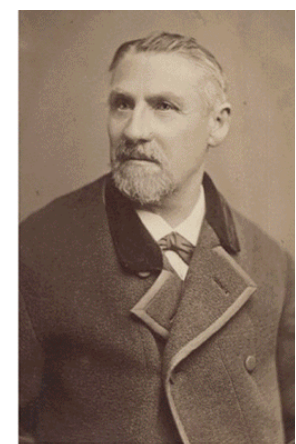

(d)

(b)
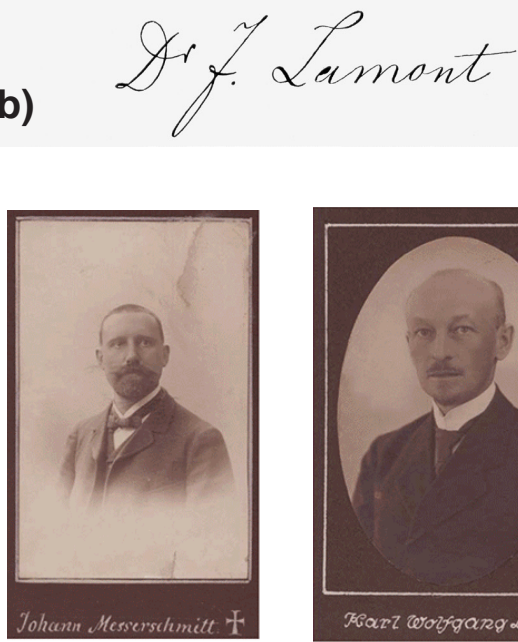

(f)

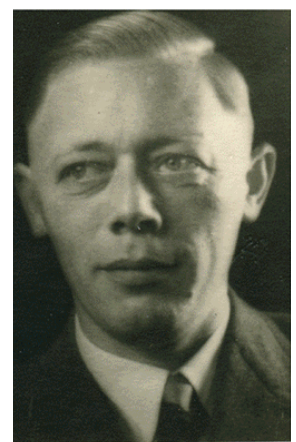

(j)

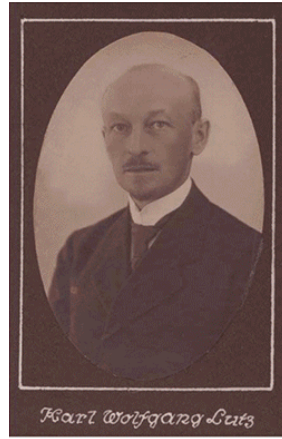

(g)

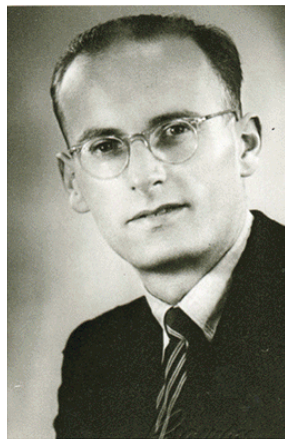

(k)

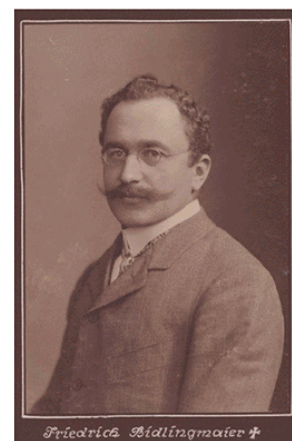

(h)

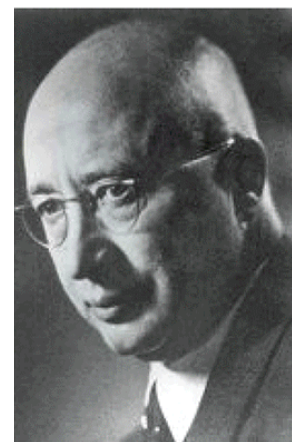

(I)

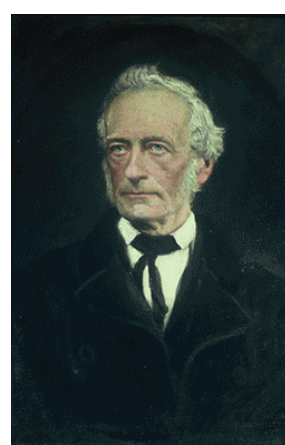

(c)

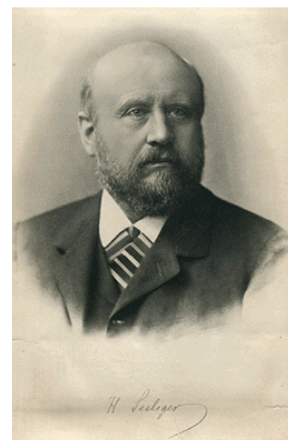

(e)

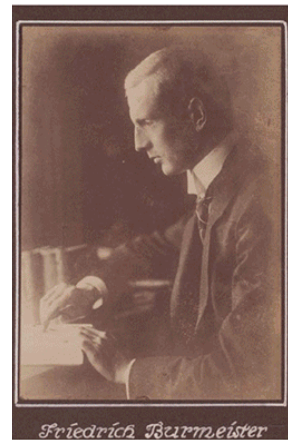

(i)

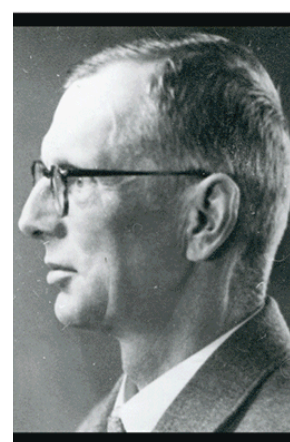

(m)

Plate 1. 


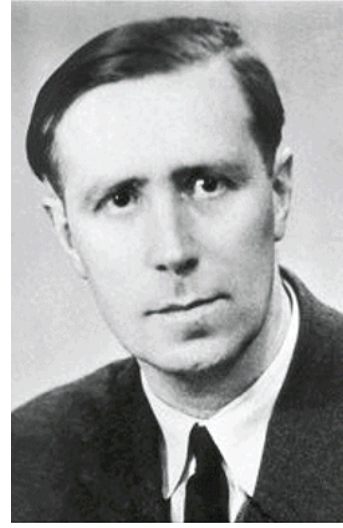

(n)

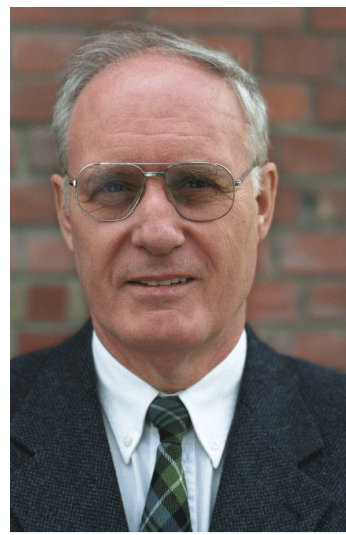

(r)

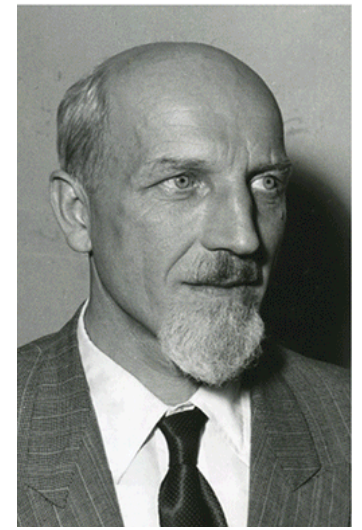

(0)

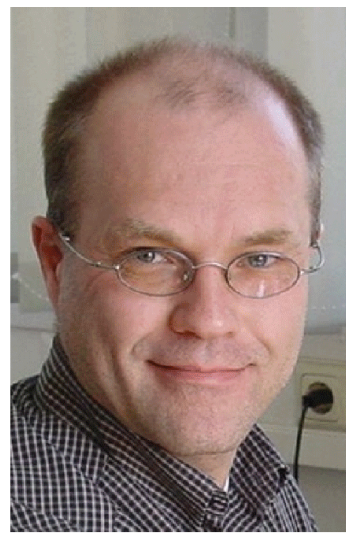

(s)

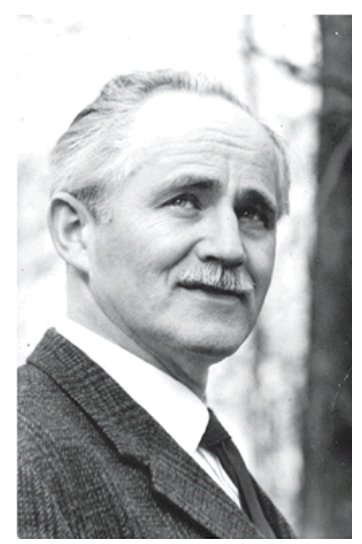

(p)

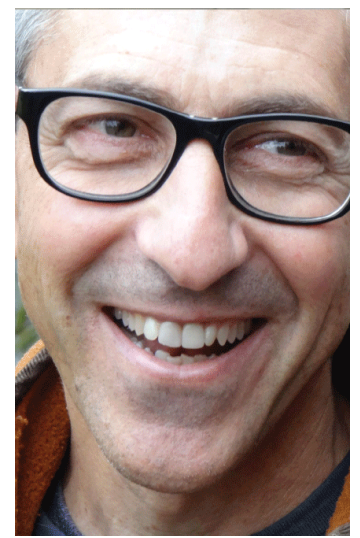

(t)

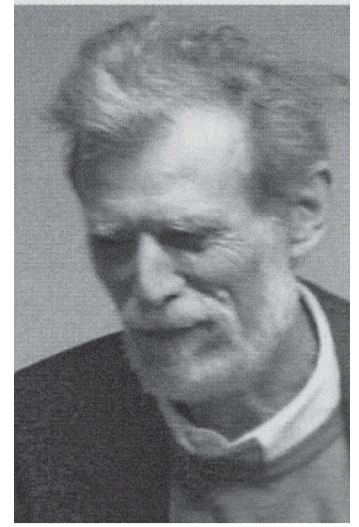

(q)

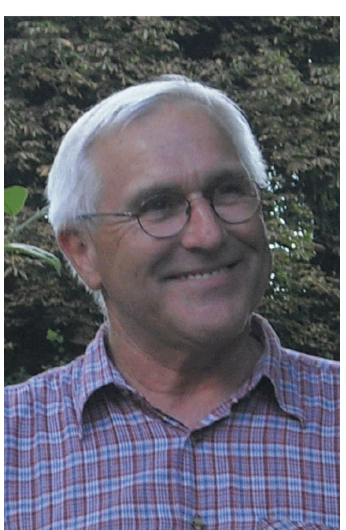

(u)

Plate 1. Portraits of the persons related to the history of the Munich-Maisach-Fürstenfeldbruck Geomagnetic Observatory. (a) Georg von Soldner (1776-1833). (b) Johann (John) Lamont (1805-1879). The figure shows him at the age of about 50. It is the earliest portrait of him. (c) Lamont in his late years. It was painted posthumously using a photograph of him taken around 1875. (d) Christian Feldkirchner (1823-1886). (e) Hugo von Seeliger (1849-1924). (f) Johann Baptist Messerschmitt (1861-1912). (g) Karl Wolfgang Lutz (1878-1946). (h) Friedrich Bildlingmaier (1875-1914). (i) Friedrich Burmeister (1890-1969). (j) Walther Oberbauer (1905-1945). (k) Kurt Burkhart (*1913). (l) Hermann Reich (1891-1976). (m) Friedrich Burmeister (1890-1969). Observer from 1919 to 1957. Late portrait of him. (n) Gustav Angenheister (1917-1991). (o) Karl Wienert (1913-1992). (p) Alex Korschunow (1918-2005). (q) Martin Beblo (*1942). (r) Heinrich Soffel (*1936), wearing a tie of the Lamont clan. (s) Hans-Peter Bunge $(* 1964)$. (t) Stuart Gilder $(* 1962)$. (u) Martin Feller $(* 1952)$.

At a meeting in 1828 of the Society of German Naturalists and Physicians (GDNÄ) in Berlin, von Humboldt had urged Gauss to get more involved in geomagnetism. One of the first results of this initiative was that Gauss invented in 1832 (Gauss, 1833) a new method for the determination of the horizontal component of the geomagnetic field and the strength (magnetic moment) of a magnet in the new metric units $\mathrm{mm}, \mathrm{mg}$ and s. In 1834 they together founded the Göttingen Geomagnetic Union (Göttinger Magnetischer Verein) which aimed at the worldwide collection of recent geomagnetic data (declination, inclination and field intensities) for analysis and better description of the field. They also suggested that new geomagnetic observatories should be founded in as many places as possible all over the world. It was generally be- lieved that a global observation of the field over a period of 5 years would be sufficient to solve all existing problems of geomagnetism. We know now that this was quite naïve. Nevertheless, the initiative was successful because in the years after 1840 the number of observatories rose to about 12 and remained almost constant until further increases after 1880 stimulated by the First International Polar Year and again in the early 1930s during the Second International Polar Year. A third upswing took place after the first International Geophysical Year in 1957.

In 1839 Lamont was asked by the Royal Society in London to participate in the activities of the Magnetic Union. He tried without success to obtain financial support from the Bavarian Academy of Sciences and the Bavarian Government to 


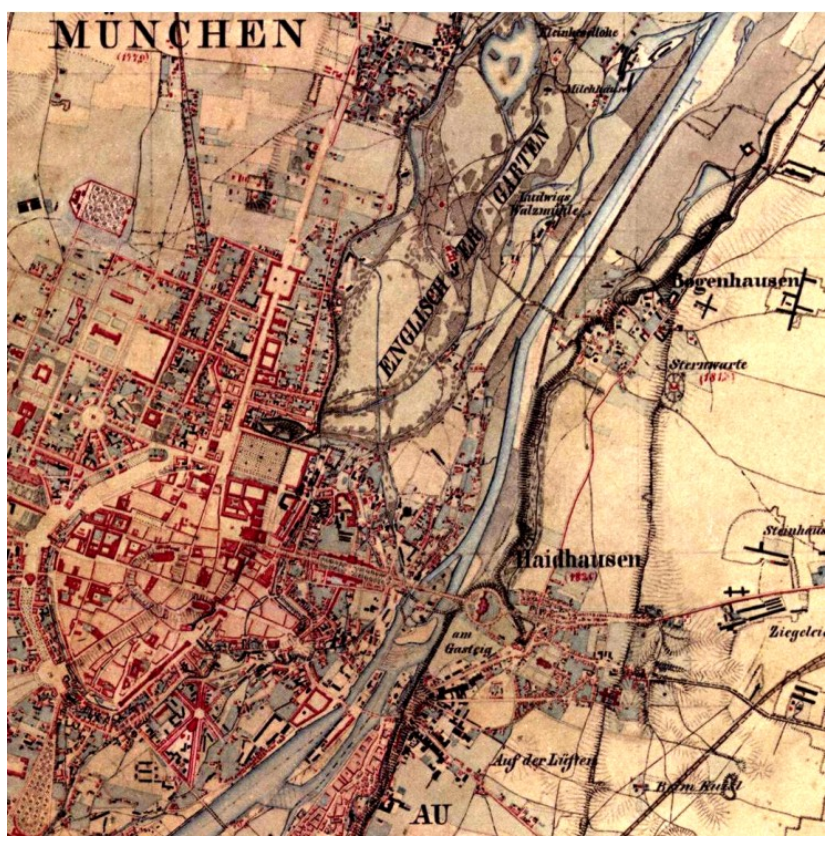

Figure 1. Partial view of the plan of Munich from 1820. In the Munich suburb of Haidhausen a small astronomical observatory existed before a new observatory building (Sternwarte) was built in $1816 / 1817$ in the rural environment near the village of Bogenhausen.

be able to set up a laboratory for regular geomagnetic observations and to buy the necessary instruments, which consisted in those days mostly of magnets of high quality and stability. Finally, on 17 January 1840, Lamont obtained 800 Fl from the Royal Bavarian Family (Burmeister, 1941). The main supporter of Lamont's request with additional $400 \mathrm{Fl}$ was Crown Prince Maximilian, later King Maximilian II (1811-1864), who was very interested in the promotion of science. For the geomagnetic observations, a partially subsurface wooden construction (Fig. 2a) was erected which was connected to the main building by a tunnel (Fig. 2b). A window in the roof allowed the observation of the spire of the church of St. Anna in Munich for the determination of the declination. Details of the first observatory and its instrumentation were given by Lamont in a report to the Bavarian Academy of Sciences (Lamont, 1841). The regular observations of declination $D$, horizontal intensity $H$ and inclination $I$ began on 1 August 1840 at 6:00 in the morning. Initially, hourly readings were taken over several weeks by Lamont and his two technicians to test the equipment; fewer readings were taken in later times. This first facility for the measurements was abandoned in 1846 because the wooden construction could no longer be used, and after 1847 the instruments were transferred to a smaller subsurface laboratory closer to the main building (Fig. 2b). After 1848 night-time measurements were discontinued. In later years additional laboratories were built at other sites of the Astronomical Observatory for the determination of absolute values of the field and its temporal variation.

\section{Development of new instruments}

The initial equipment of Lamont's observatory was bought from Gauss and Meyerstein in Göttingen. It consisted mainly of quite heavy magnets $(11.7 \mathrm{~kg})$. Very soon Lamont realized that he had to replace these inconvenient instruments by equipment of his own design. Together with his technicians he set up a workshop in his living room in the Astronomical Observatory. Later it became the official workshop of the observatory. Lamont's education in mechanics in Regensburg now turned out to be very valuable. The new systems of Lamont used much smaller and lighter magnets of just a few grams (Lamont, 1842, 1846). The suspended magnets were protected against air turbulence by a glass cover (Fig. 3) and could easily be handled. For the determination of the horizontal intensity of the geomagnetic field, he changed the position of the deflecting magnet in relation to the compass needle. This "Lamont position" had some advantages over the configuration used by Gauss in his classical experiment of 1832 .

When Lamont started his observatory, automatic recording systems of the temporal variations of geomagnetic parameters were in their infancy and very expensive. Due to his limited budget, he had to look for other solutions to replace the time-consuming direct observations of the temporal variations of the field. From 1847, he used wax-covered, slowly rotating, cylinders into which sharp tips on the lower side of the suspended magnet punched small depressions when the magnets were lowered each hour by a mechanism controlled by a clock (Fig. 4). The data could later by read from the surface of the cylinder using a microscope of low magnification. Later Lamont also used similar systems for the recording of temperature and pressure variations during his meteorological studies. However, for this automatically recording magnetograph, he was obliged to return to heavier magnets. This simple but inexpensive method for the recording of temporal variations was continued until 1872. In the years following, only regular absolute measurements of $D, H$ and $I$ were continued and the variations were no longer measured. However, the recording of temporal geomagnetic variations was resumed several decades later under Franz von Schwarz (1847-1903), who had become responsible for the geomagnetic measurements, and a new laboratory for the recording of temporal variations was built.

\section{Lamont's nonmagnetic theodolite (Reisetheodolit) and his regional geomagnetic surveys}

During the 1840s Lamont developed an instrument for the measurement of the geomagnetic parameters $D, H$ and $I$, not only under laboratory conditions, but also at field sta- 
(a)

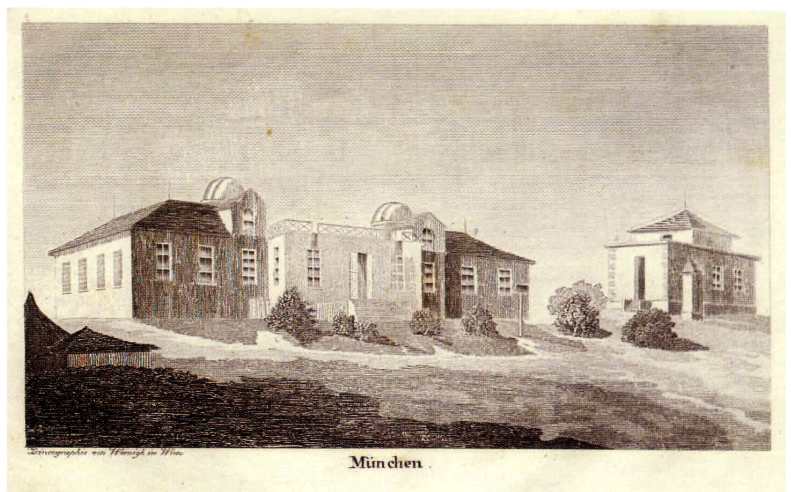

(b)

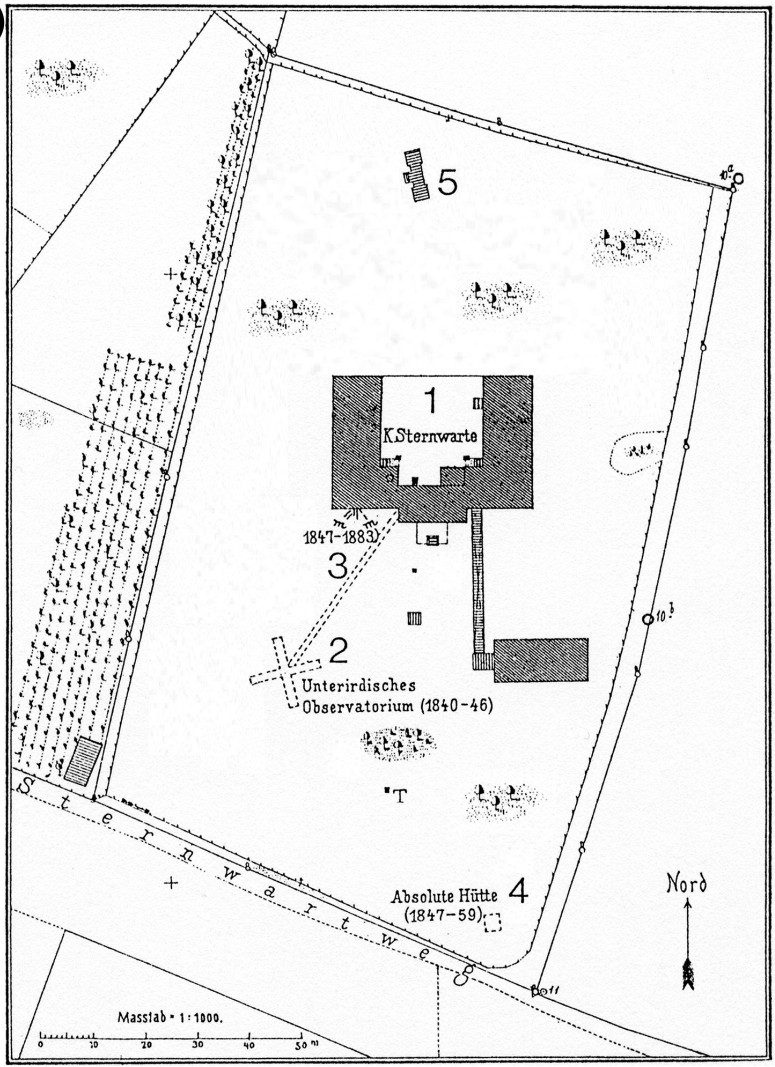

Figure 2. (a) The Astronomical Observatory in Bogenhausen; picture from the mid-1840s. On the left-hand side the roof of the partially subsurface geomagnetic observatory can be seen. The building on the right side contains the new telescope which was installed in 1834. (b) Plan of the Astronomical Observatory with the buildings and sites for geomagnetic measurements between 1840 and 1879, the time during which Johann von Lamont was its director. (1) Main building. (2) Partially subsurface observatory from 1840 to 1846 . (3) Position of the instruments for the measurements of $D$, $H$ and $I$ between 1847 and 1883. (4) Building for absolute measurements between 1847 and 1859. (5) Building for absolute measurements between 1859 and 1886 . tions. The result of many experiments with prototypes was finally his famous Reisetheodolit (Fig. 5a-c). Lamont tested his new instrument in the early 1850 s during several visits to other geomagnetic observatories in Europe, such as Utrecht, Stockholm, London and Paris. Eventually, he was convinced that the Reisetheodolit was a convenient and sufficiently accurate instrument to make geomagnetic survey measurements on a regional scale. He also succeeded in obtaining travel funds from the Bavarian Academy of Sciences for a geomagnetic survey of the kingdom of Bavaria, comprising most of southern Germany including the Palatinate, a region also belonging to Bavaria on the western side of the river Rhine. The measurements were carried out by Lamont between 1849 and 1854 with the help of a technician of the observatory. During that time he also collected other geomagnetic data obtained in the previous years in central Europe by other members of the Göttingen Magnetic Union, and, after correcting them for secular variation, produced maps for $D, H$ and $I$ for southern Germany (Lamont, 1854a) and central Europe (Lamont, 1854b). Figure 6a, b show the declination maps. All maps, also including those for $H$ and $I$, and information about the measurement points have been republished by Soffel (2005d).

Encouraged by the positive response, he planned to conduct similar surveys in other European countries. For this he used private funds as well as travel funds from the Bavarian government, where King Maximilian II (who had already supported Lamont's plans to build a geomagnetic observatory) had just started a new programme to support science in his kingdom. Lamont was able to carry out geomagnetic surveys in France, Spain, Portugal, Belgium, the Netherlands and finally also in Prussia (Lamont, 1858, 1859). The maps have also been republished by Soffel (2005d). They were in most cases the first geomagnetic regional survey maps for these countries and stimulated similar regional geomagnetic measurements in other parts of the world. The Reisetheodolit became the international standard instrument during this time. In the following years, 45 instruments were built in the workshop of the observatory and sold for a price of ca. $400 \mathrm{Fl}$ to many observatories and expeditions in all parts of the world.

In 1852, after a 12 year long observation of the field, Lamont discovered that the intensity of magnetic disturbances of $D$ and $H$ changed with time, indicating a periodicity of about 10 years. A similar effect had also been found by Edward Sabine (1788-1883) in the data of the observatory in Toronto in Canada. Neither connected this observation to the 11 year periodicity of sunspots. It was the astronomer Rudolf Wolf (1816-1893), Director of the Swiss Astronomical Observatory in Zürich, who stated on 10 May 1852: "The temporal variations of the magnetic needle measuring the declination have the same periodicity as sun spots". This observation showed for the first time the very important relationship between the geomagnetic field and physical processes in the sun. 


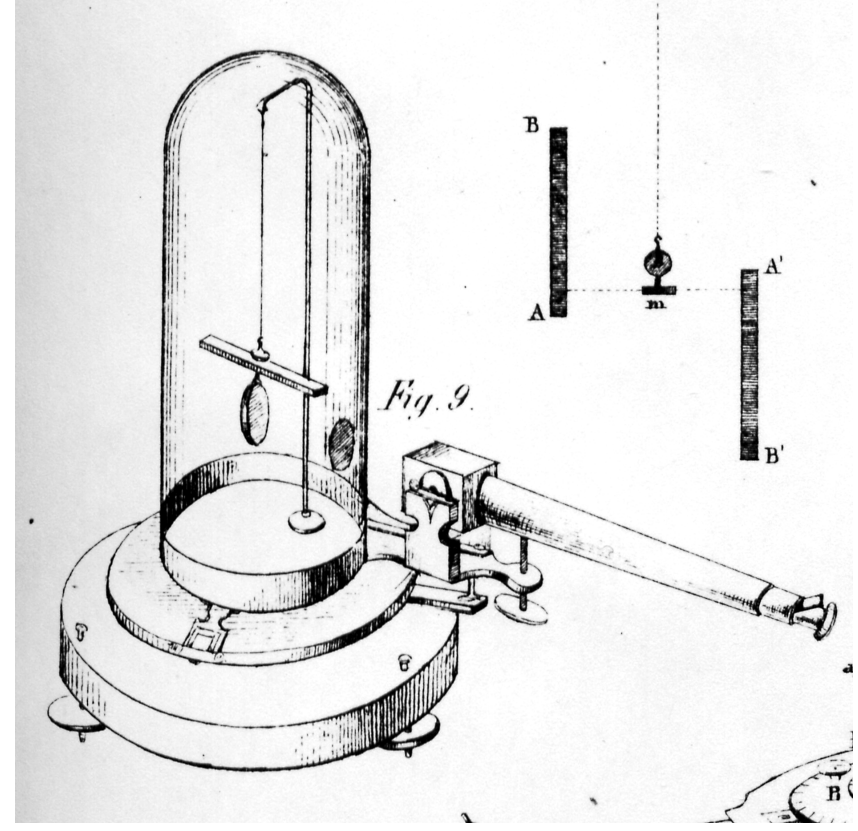

Figure 3. Lamont's instruments with small magnets, protected by a glass cover from air turbulences. The device developed by Lloyd for the measurement of the inclination using rods of soft iron is shown on the upper right side of the figure.

At the end of the 1850s Lamont installed on the site of the observatory a N-S-directed and a W-E-directed line where he measured continuously the difference of the electrical potential between the endpoints. He was one of the first who discovered that the potential differences correlate with variations of the geomagnetic field (Lamont, 1862). This discovery is fundamental for modern geophysical methods like geoelectrics und magnetotellurics (Angenheister, 1991; Haak, 1991, 2014). From the ratio between the orthogonal amplitudes of the magnetic and the electric field variations, he concluded that the sedimentary basin underneath Munich should have a thickness of about $1.5 \mathrm{~km}$. This value would be confirmed more than 100 years later with reflection seismology.

\section{Lamont's later years}

In 1852 Franz von Paula Gruithusen (1774-1852), who held the Chair for Astronomy at the University of Munich, died, and Lamont became his successor. This allowed him to give lectures in astronomy as well as in geomagnetism and to have his own students. Probably the most famous was Georg von Neumayer (1826-1909). Using Lamont's instruments he undertook pioneering geomagnetic work in Australia and founded the Flagstaff Observatory in 1858 (Schröder et al., 2010). He also carried out geomagnetic measurements in Antarctica. During that time Lamont continued his astronomical routine work, albeit with reduced enthusiasm, also began meteorological measurements in the observatory, collected

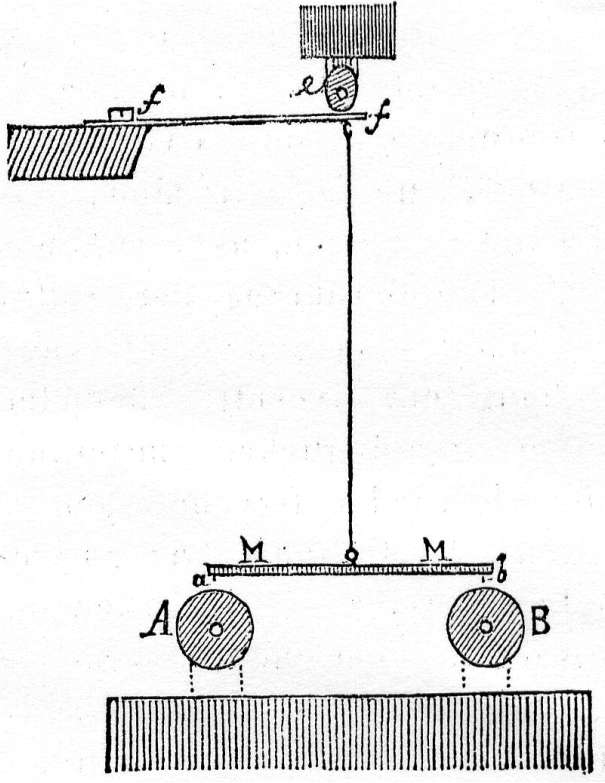

Figure 4. Automatic recording system developed by Lamont in 1847 for the hourly recording of temporal variations of geomagnetic parameters consisting of wax-coated slowly rotating cylinders. Every hour the suspended magnet is lowered and tips at the bottom of the magnet punch depressions into the wax. The data could be read with a microscope of small magnification.

meteorological data compiled by monks of the monastery of Hohenpeißenberg in southern Bavaria during the eighteenth century, and participated in geodetic surveys. More about these side activities can be taken from Häfner and Soffel (2006). In 1867 Lamont was ennobled by King Ludwig II and allowed to call himself Johann von Lamont. He was also a member of many famous academies in Europe and had become Honorary Citizen of Bogenhausen in 1878. On 6 August 1879 he died peacefully in his home in the observatory building. Plate $1 \mathrm{c}$ shows a portrait of him painted a few years after his death. Lamont is buried in the cemetery of the church of St. Georg in Bogenhausen (Fig. 7), which is situated just a few hundred metres from the observatory where he had lived for more than 45 years. In 1934 the Lamont Clan in Scotland erected a monument for the famous clan member. It stands in Inverey in front of the still existing old school (Fig. 8a, b) where Lamont had his first lessons as a schoolboy. Astronomers gave his name to craters on both the Moon and Mars.

Towards the end of Lamont's time all the instruments of the Geomagnetic Observatory were in bad condition and their accuracy was reduced compared with previous decades. The quality of the data became worse from year to year and horizontal intensity and inclination could no longer be measured with sufficient accuracy. Therefore, annual means were not determined. This can be taken from the graphs that run from 1840 to 2014 (Fig. 17a-c). Already in Lam- 
(a)

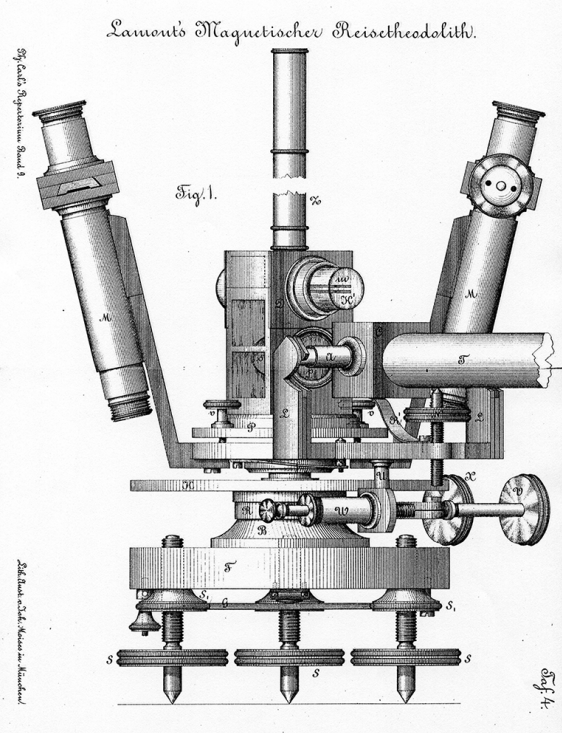

(b)

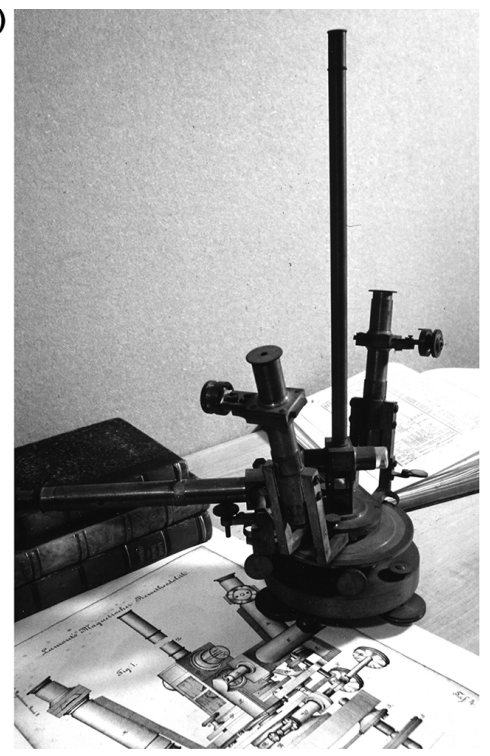

(c)

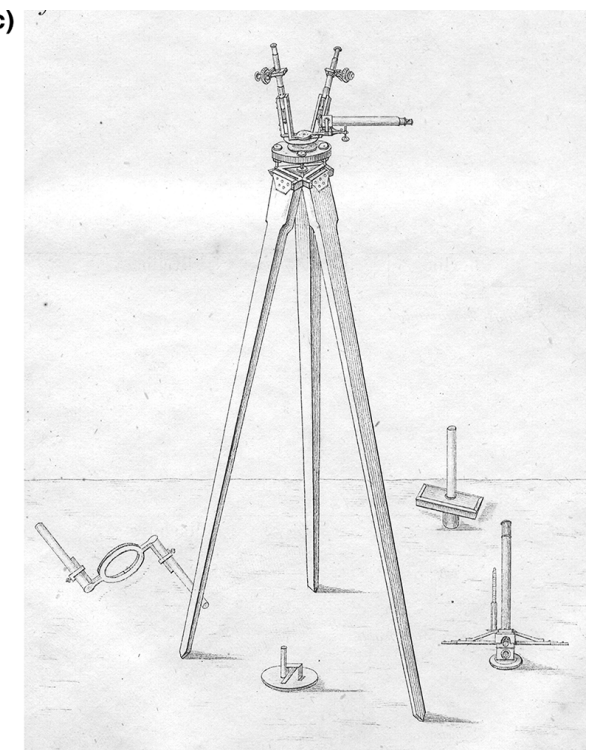

Figure 5. Lamont's nonmagnetic theodolite (Reisetheodolit). (a) Construction drawing of the instrument. (b) Photograph of the instrument in our observatory. (c) Theodolite mounted on a tripod and additional equipment for measurements of $D, H$ and $I$ in the field.

ont's last years only the declination was measured and annual means were calculated. After 1879, Lamont's assistant Christian Feldkirchner (1823-1886, Plate 1d) continued some of the absolute measurements using Lamont's old and worn-out equipment. When Feldkirchner died in 1886, all geomagnetic measurements ended, and the observatory practically ceased to exist.

\section{History of the Geomagnetic Observatory in the years following Lamont}

The successor to Lamont as Director of the Astronomical and Geomagnetic Observatory from 1882 on was Hugo von Seeliger (1849-1924, Plate 1e), an astronomer of high reputation. He had allowed Feldkirchner to continue the geomagnetic measurements, but stopped them after his death in 1886 . In those years the general interest in geomagnetism within the Bavarian Academy of Sciences was rather low. However, there was considerable pressure from the geomagnetism community outside to continue the work of the Geomagnetic Observatory in Munich. In the meantime a new geomagnetic observatory in Potsdam in Prussia had been founded in 1891. The first International Polar Year in the early 1880s which had stimulated many new observatories all over the globe as well as the well-known rivalry between Prussia and Bavaria may have added to the stimulus from outside. It was therefore decided by the Academy in 1891 to resume the geomagnetic measurements in Munich. However, it took some time to find a proper person to bring the observatory back to its former status.

Franz von Schwarz (1847-1903) was appointed in 1897 by the Academy to restart geomagnetic measurements. He had been one of Lamont's students and had left Munich to work in Russia, where he had become Director of the Astronomical Observatory of Tashkent. Because of Seeliger's other interests and expertise, the status of the Geomagnetic Observatory also had to be changed. It now became an institution of its own within the Academy with a separate budget and was therefore no longer an appendage of the Astronomical Observatory. Von Schwarz insisted that new and separate buildings should be erected on the site of the observatory for the measurement of the absolute values and temporal variations of the field. The old worn-out instruments of the Lamont era were replaced by modern equipment with higher accuracy and reliability. Details can be taken from the Appendix. From 1898 onward, when the new buildings were finished and the old ones restored (Fig. 9a, b), the Munich Geomagnetic Observatory was back in business. A plan from 1904 for all buildings on the site of the Astronomical Observatory is shown in Fig. 10.

The decision in 1891 to resume the geomagnetic measurements at the site of the Astronomical Observatory was doomed from the start because it was already known that the city had plans to extend a tramway line from downtown Munich to Bogenhausen with electric locomotives. The fatal influence of the tramway on geomagnetic measurements so close to a growing city was recognized too late. In retrospect it would have been better to give up the Geomagnetic Observatory in Bogenhausen and to build a new one farther away from the expanding city and its growing industry and traffic with its increasing geomagnetic disturbances. In the mid1890s the plans to build an electric tramway line approaching the observatory in Bogenhausen became more concrete. The distance between the observatory and the terminal of the 
(a)

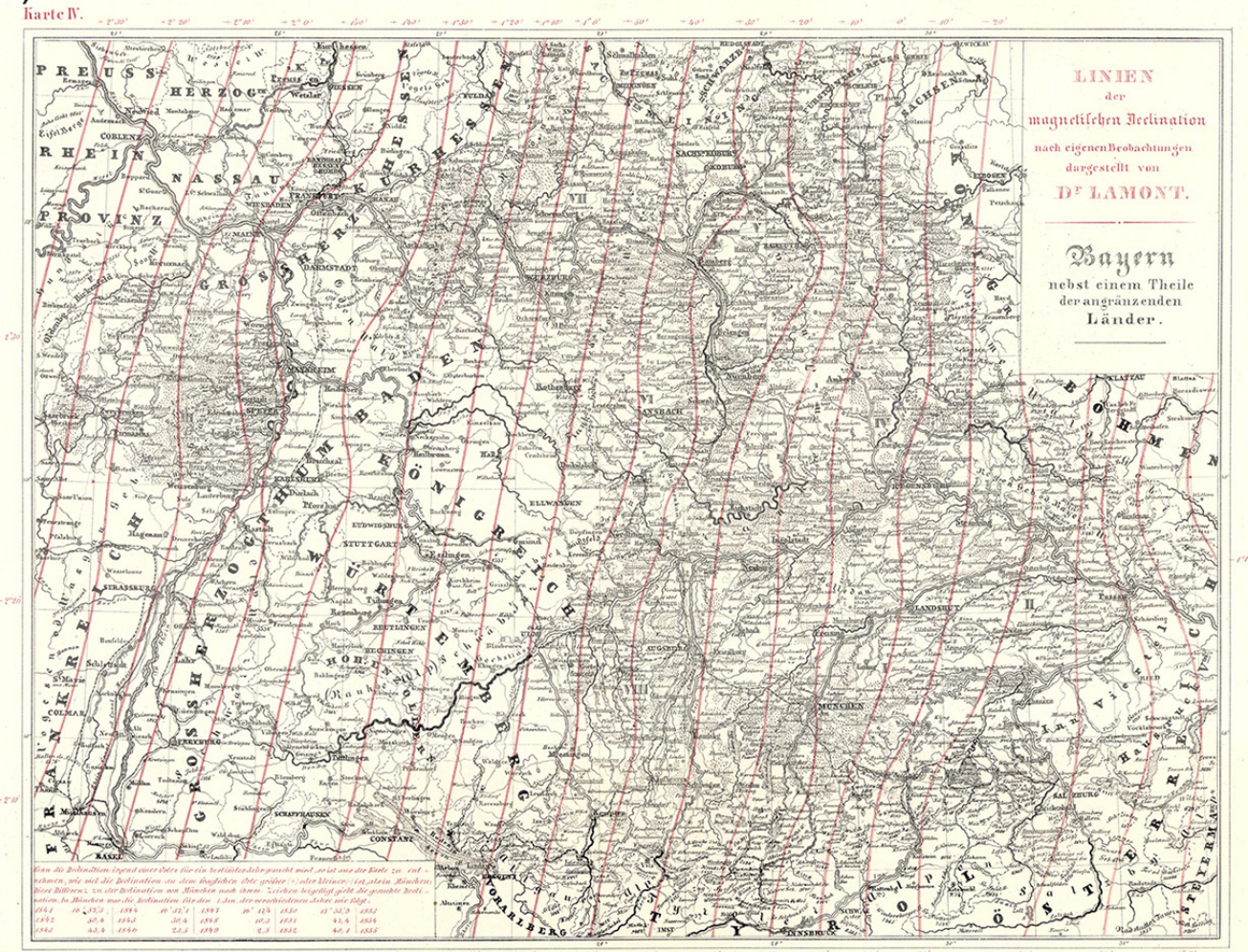

(b)

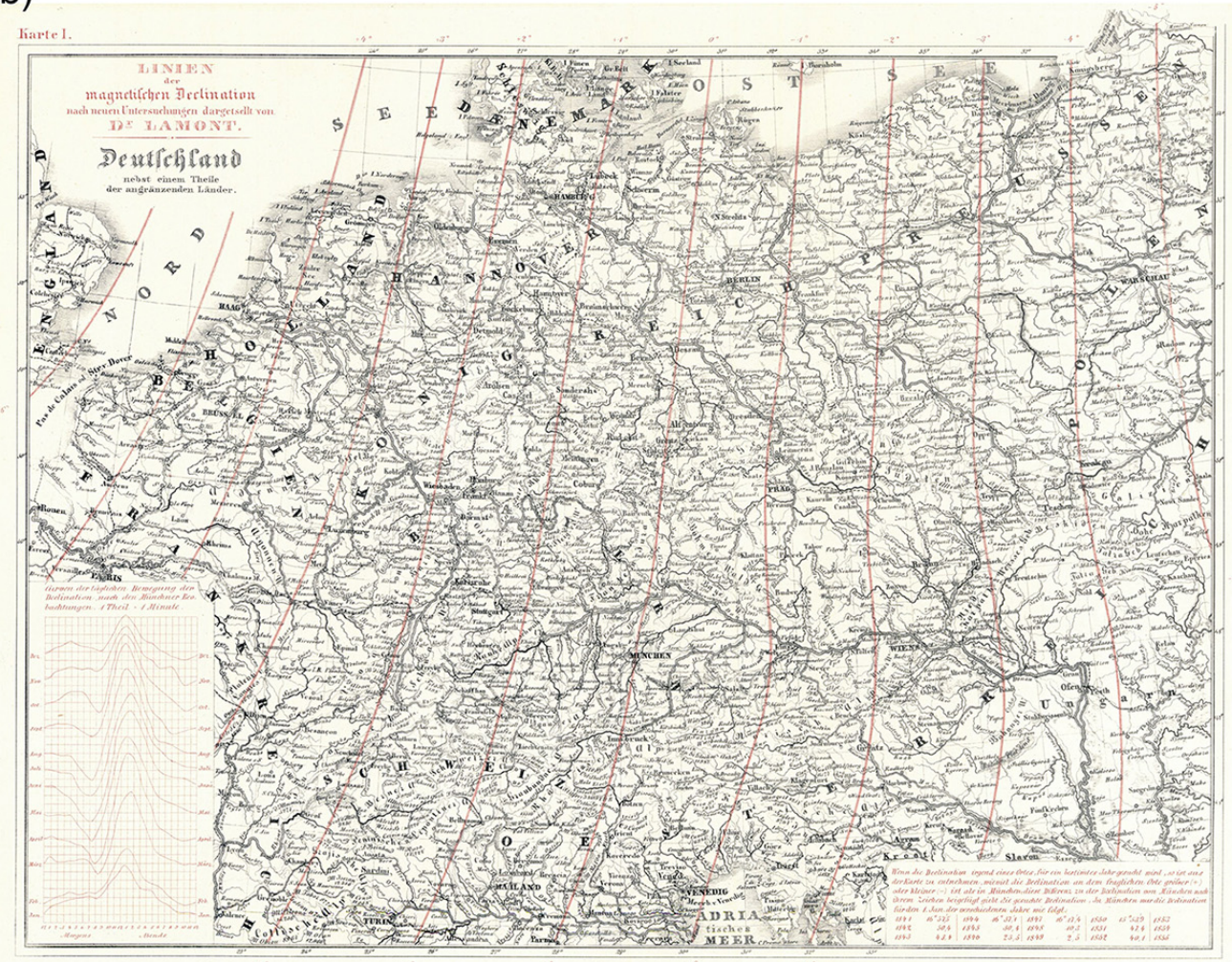

Figure 6. Maps showing the declination reduced to 1 January 1850 in Munich where $D$ had a value of $-15^{\circ} 53.9^{\prime}$ E. (a) Southern Germany (Lamont, 1854a). The eastern declination decreases towards the east. Each isoline represents a change of 10 min. (b) Central Europe (Lamont, 1854b). Each isoline represents a change of $1^{\circ}$. 


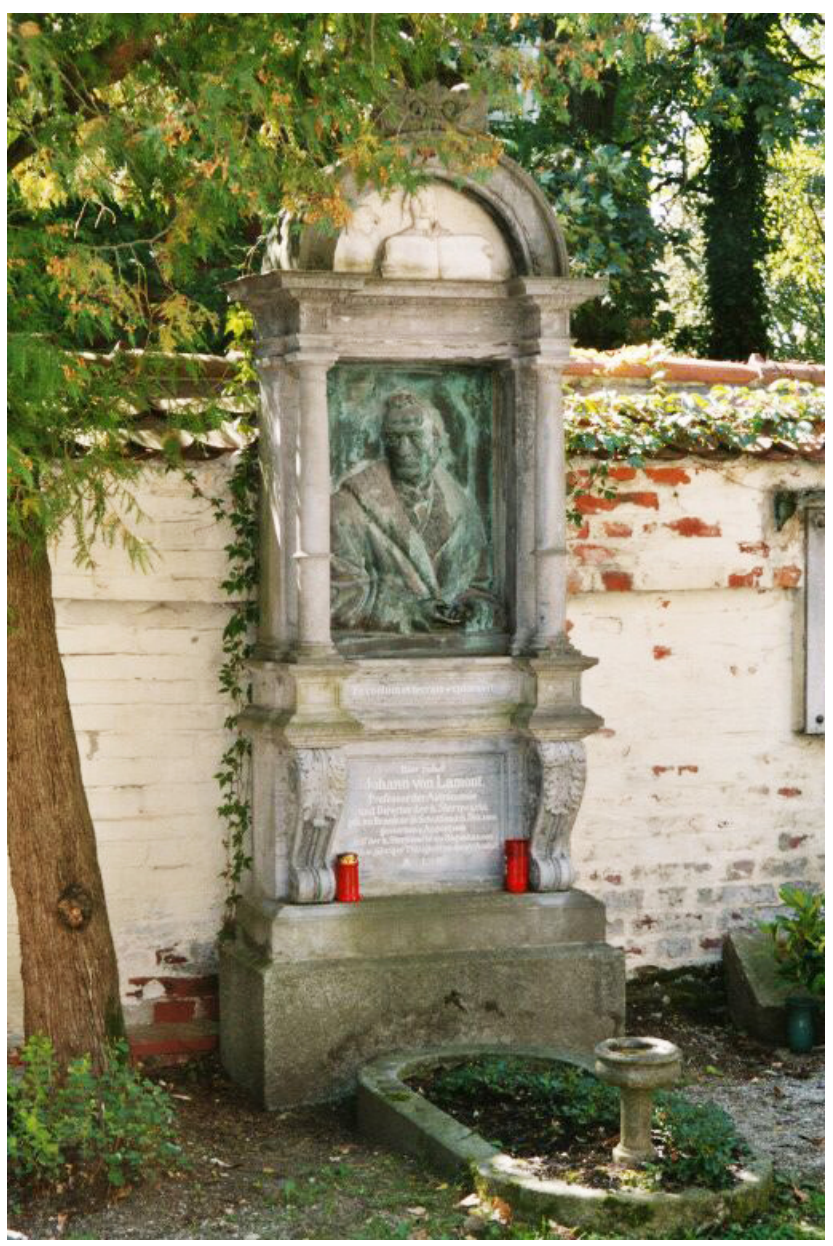

Figure 7. Lamont's grave in Bogenhausen. It has the incription Et Coelum Et Terram Exploravit - He Explored the Heavens and the Earth.

planned tramway line was just $200 \mathrm{~m}$. This alerted the scientists of the observatory.

Franz von Schwarz discovered an important article by Kohlrausch (1840-1910) describing the possible influence of electric trams on the work of a geomagnetic observatory. Kohlrausch, the President of the State Institute for Physics and Technology in Berlin (Physikalisch-Technische Reichsanstalt), had discovered that delicate physical measurements in Berlin and other cities can be strongly affected by magnetic stray fields from electric tramway systems. In Berlin he carried out systematic measurements, published in 1895 (Kohlrausch, 1895). He found out that magnetic stray fields due to the iron masses of the tramway carriages and of the rails can be neglected at a distance of a few hundred metres. However, the magnetic fields resulting from the direct currents can still be noticed at large distances (several $\mathrm{km}$ ) from the rails and the tramway lines. For Kohlrausch it was evident that the disturbances of an electric tramway system were so large that a distance of several $\mathrm{km}$ would be necessary to al- low precise measurements of magnetic fields in laboratories and observatories.

Alarmed by the 1895 publication of Kohlrausch, in 1897 Franz von Schwarz asked the Director of the Astronomical Observatory, Hugo von Seeliger, to inform the Director of the Academy as his immediate superior and the corresponding Bavarian Ministry about the dangers of electric tramway systems with overhead wires for a geomagnetic observatory. Von Seeliger expected that the Ministry would protect the new Geomagnetic Observatory, already restored at high costs, against the harmful influences of a nearby electric tramway. A copy of the publication by Kohlrausch from 1895 was added. Hugo von Seeliger requested that only locomotives powered by batteries should be used for the tramway lines operating near the observatory and that all tramway lines should not get closer to the observatory site than 200 to $300 \mathrm{~m}$. Test measurements were made using a declinometer of the observatory in a building about $200 \mathrm{~m}$ away from the terminal of an already existing tramway line. All participants in the test concluded in their report that there would be no effect on the Geomagnetic Observatory from the planned electrified tramway line. However, Franz von Schwarz accepted this conclusion only after some pressure from the others. As a physicist he knew that the declinometer was only able to detect changes in the horizontal intensity of the field, while the currents of the tramway system mostly produced changes in the vertical component. However, such an instrument was not available for the test measurements. Therefore he believed that the experiment proved nothing. He also informed the authorities that the US Marine Observatory in Washington DC and the observatory in Toronto had to be abandoned because of the magnetic noise due to electric tramways. In the end it was decided by the Bavarian Ministry of the Interior to build an electrified tramway line from downtown Munich to Bogenhausen despite the arguments of the experts of the Geomagnetic Observatory. However, a protected zone around the observatory of radius $300 \mathrm{~m}$ was granted to minimize magnetic noise due to industrial activity in its close vicinity. Unfortunately Franz von Schwarz fell ill in 1902 and died in 1903.

\section{History of the Geomagnetic Observatory during the first decades of the twentieth century}

After Franz von Schwarz, Johann Baptist Messerschmitt (1861-1912, Plate 1f) continued the geomagnetic measurements from 1902 to 1912. He had studied mathematics and astronomy in Zürich, Leipzig and Erlangen. When the electric tramway line from Munich to Bogenhausen came into operation, the situation worsened from year to year. Special recordings and test measurements were made by the scientists to demonstrate the influence of the tramway, of the expanding industry and later also of motorcars on the quality of geomagnetic data. As a consequence, absolute measurements 
(a)
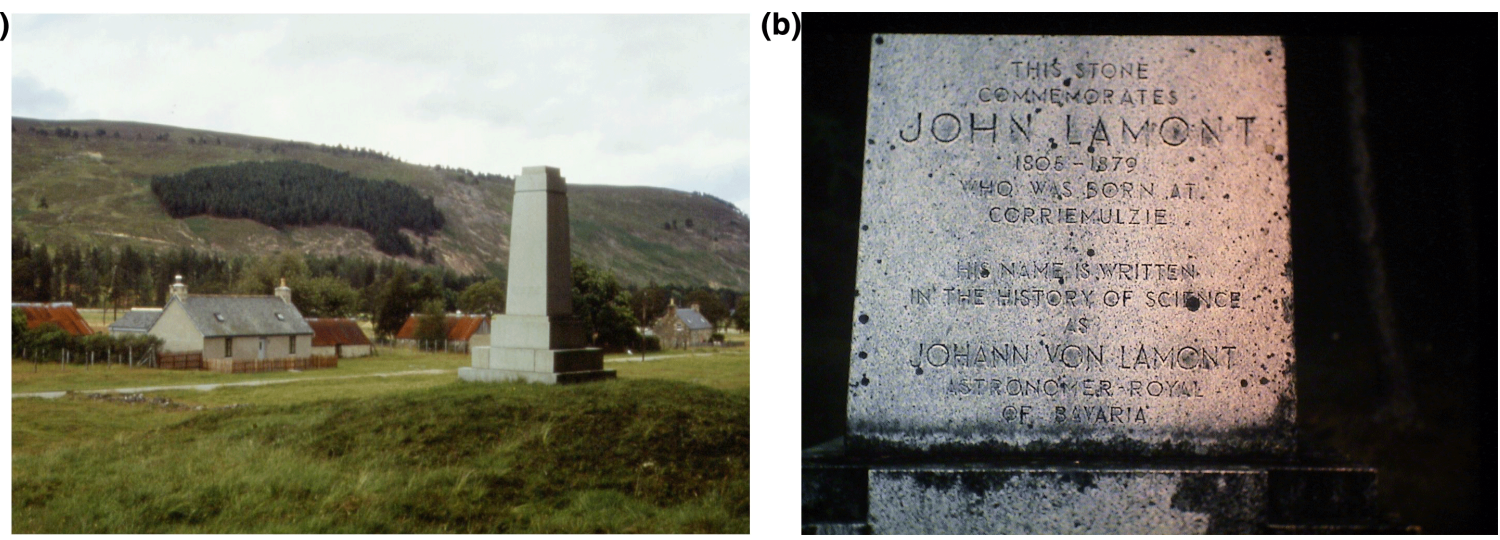

Figure 8. (a) Monument for Lamont in front of his old school building in Invery. (b) Inscription on the monument: "This stone commemorates John Lamont, 1805-1879, who was born at Corriemulzie. His name is written in the history of science as Johann von Lamont, Astronomer Royal of Bavaria".

(a)

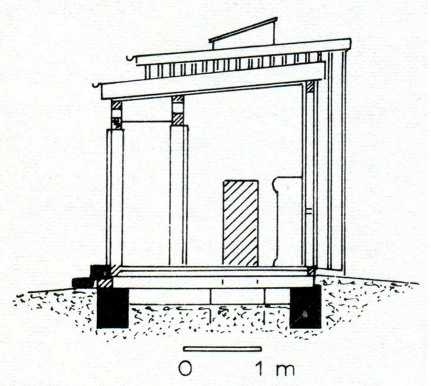

(b)

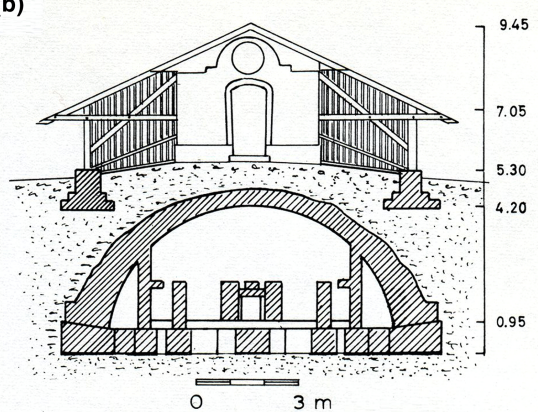

Figure 9. New buildings for the Geomagnetic Observatory on the site of the Astronomical Observatory (see also Fig. 10). (a) Building for absolute measurements. It was established in 1859 and restored in 1898. (b) New partially subsurface building from 1898 for the measurement of the temporal variations. Both laboratories were equipped with new instruments.

became more and more unreliable and could only be made at night when the tramway traffic stopped and industrial activity was low. The sporadic observations of the temporal field variations were given up completely in 1914 .

Messerschmidt repeated Lamont's regional geomagnetic survey for Bavaria between 1903 and 1905 (Fig. 11) with a modern nonmagnetic theodolite built by Tesdorpf, because Lamont's Reisetheodolit could no longer be used (Messerschmitt, 1906). He found that the secular variation in Bavaria during the preceding 50 years was quite smooth and did not show any local effects. In 1911 Messerschmitt wrote a document (Denkschrift) describing the situation of the observatory, demanding a solution. Of course, the arguments of the scientists were not able to stop the industrial and other forms of development of the city. The first plans to move the Geomagnetic Observatory to a better place began at this time, but they were interrupted by World War I between 1914 and 1918 and the critical political and economic situation in Germany in the years afterwards. The foundation of a seismic observatory in 1905 on the site of the Astronomical Observatory in Bogenhausen by Messerschmitt should also be mentioned here, although its history will not be presented in this paper. Karl-Wolfgang Lutz (1878-1946, Plate 1g) was appointed as scientist in charge of this new branch of the observatory. Besides seismology, he also had interests in atmospheric electricity. The seismic observatory ceased to exist in 1943, when it was destroyed by bombs during the Second World War.

When Messerschmitt died in 1912 the remaining scientist, K. W. Lutz, also took over the geomagnetic measurements. However, quite soon Friedrich Bidlingmaier (18751914, Plate 1h) was appointed. He had studied mathematics and physics in Tübingen, Dresden and Göttingen. Due to his participation in the expedition of Erich von Drygalski (1865-1949) to the Antarctic from 1901 to 1903 as geomagnetist, he was an ideal person for the position in the Munich Geomagnetic Observatory. Bidlingmaier is also well known for his special compass type. He had been appointed in 1912 but died on 23 September 1914 at the beginning of the First World War, leaving Lutz again responsible for geomagnetism in the observatory. In the years after 1898 only declination was measured continuously with appropriate accuracy. Inclination and horizontal intensity were no longer determined 


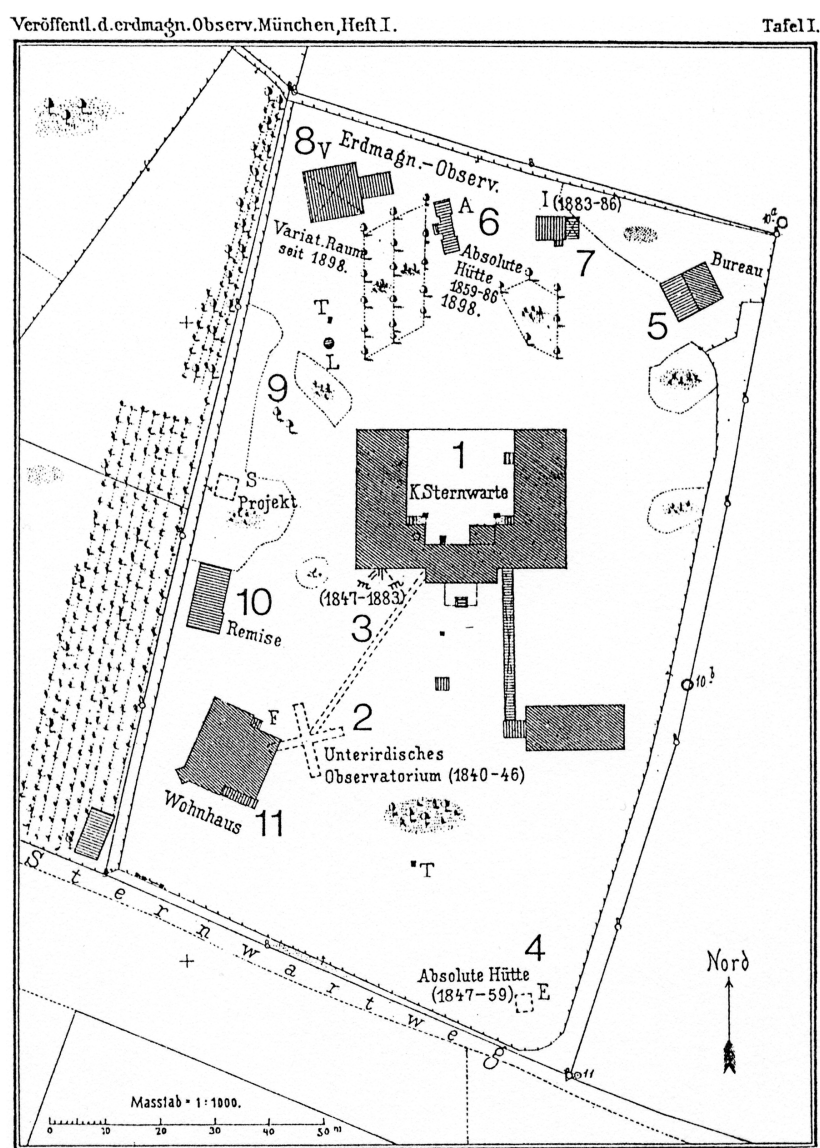

Figure 10. Map of the astronomical observatory site from 1904. (1) Main building. (2) Partially subsurface observatory from 1840 to 1846. (3) Position of the instruments for the measurements of $D, I$ and $H$ between 1847 and 1883. (4) Place for absolute measurements between 1847 and 1859. (5) Office. (6) Building for absolute measurements after 1859. (7) Laboratory. (8) Laboratory for the measurement of temporal variations. (10) Coach house and tool shed. (11) Residence of the new director, Prof. Dr. Hugo von Seeliger.

during 1914-1918 and therefore annual mean values for this period do not exist. The recording of the temporal variations of the geomagnetic field, which where discontinued in 1886 after the death of Feldkirchner, then resumed again in 1898 under Schwarz, and were stopped again in 1914.

\section{History of the Geomagnetic Observatory under Friedrich Burmeister}

In 1919 Friedrich Burmeister (1890-1969, Plate 1i) was appointed to restore the Geomagnetic Observatory; he held this position until 1957. He had studied mathematics, physics and astronomy at the Universities of Berlin and Munich and had been a student of Hugo von Seeliger and Arnold Sommerfeld (1868-1951). Although Lutz had done his best during the years after 1914 to carry on some of the geomagnetic mea- surements, the instruments and the buildings of the Geomagnetic Observatory were in very bad condition when Burmeister took over. Due to the dramatic expansion of the city of Munich with its new electric tramway lines, new industries near Bogenhausen and traffic with motorcars, the disturbances in Munich were too large for recordings of the temporal variations of the field. Absolute measurements could only be made at special times at night. As mentioned earlier, only declination measurements had been possible for many years.

Burmeister immediately started an initiative to find a new undisturbed site for the Geomagnetic Observatory. After some test measurements, he found a suitable site near the village of Maisach, a few kilometres north of the town of Fürstenfeldbruck, about $25 \mathrm{~km}$ west of Munich. The place was undisturbed and could be reached by train from Munich central railway station within about half an hour. In order to avoid the awkward transportation of the instruments for absolute field measurements between Bogenhausen and Maisach, a simple wooden hut from the observatory in Bogenhausen was taken apart and reassembled at Maisach (Maisacher Hütte, Fig. 12). The site belonged to the state and was rented to a local brewery. It was also used occasionally for the training of policemen. The brewery allowed weekly geomagnetic measurements to be carried out. More or less regular absolute measurements of $D, H$ und $I$ were performed from 1923 onward.

In 1926 Burmeister wrote a new memorandum (Denkschrift) in which he explained the present situation and asked for support to bring the observatory back to international standards. Already in 1925 he had received an encouraging letter for his plans from Prof. Dr. Adolf Schmitt, Director of the Geomagnetic Observatory in Potsdam and senior geomagnetist in Germany. Burmeister also asked the Bavarian Academy of Sciences to provide financial means for a new observatory at Maisach, which he considered to be an appropriate site. However, the economical and financial situation in Germany was very stressed in the years after the First World War. Burmeister also asked the Carnegie Institution for financial support of USD 8000. Similar petitions were also sent to the Rockefeller Foundation and to IAGA, the International Association of Geomagnetism and Aeronomy. All applications were rejected.

From 1927 onward Maisach was used more or less continuously for absolute geomagnetic measurements. In order to stabilize the instruments and to improve the quality of the data, several pillars were installed inside the Maisacher Hütte (Fig. 13). In 1931 Burmeister found out that a room in the $7.5 \mathrm{~m}$ deep basement called "Sommerkeller" of a brewery in Maisach could possibly be used for the measurement of high-quality temporal observations as well (Fig. 14). The brewery accepted having the instruments installed and operated at very low costs. The owner was even ready to take care of the instruments and helped to manage the measurements (change of films, check of the lamps, etc.). 


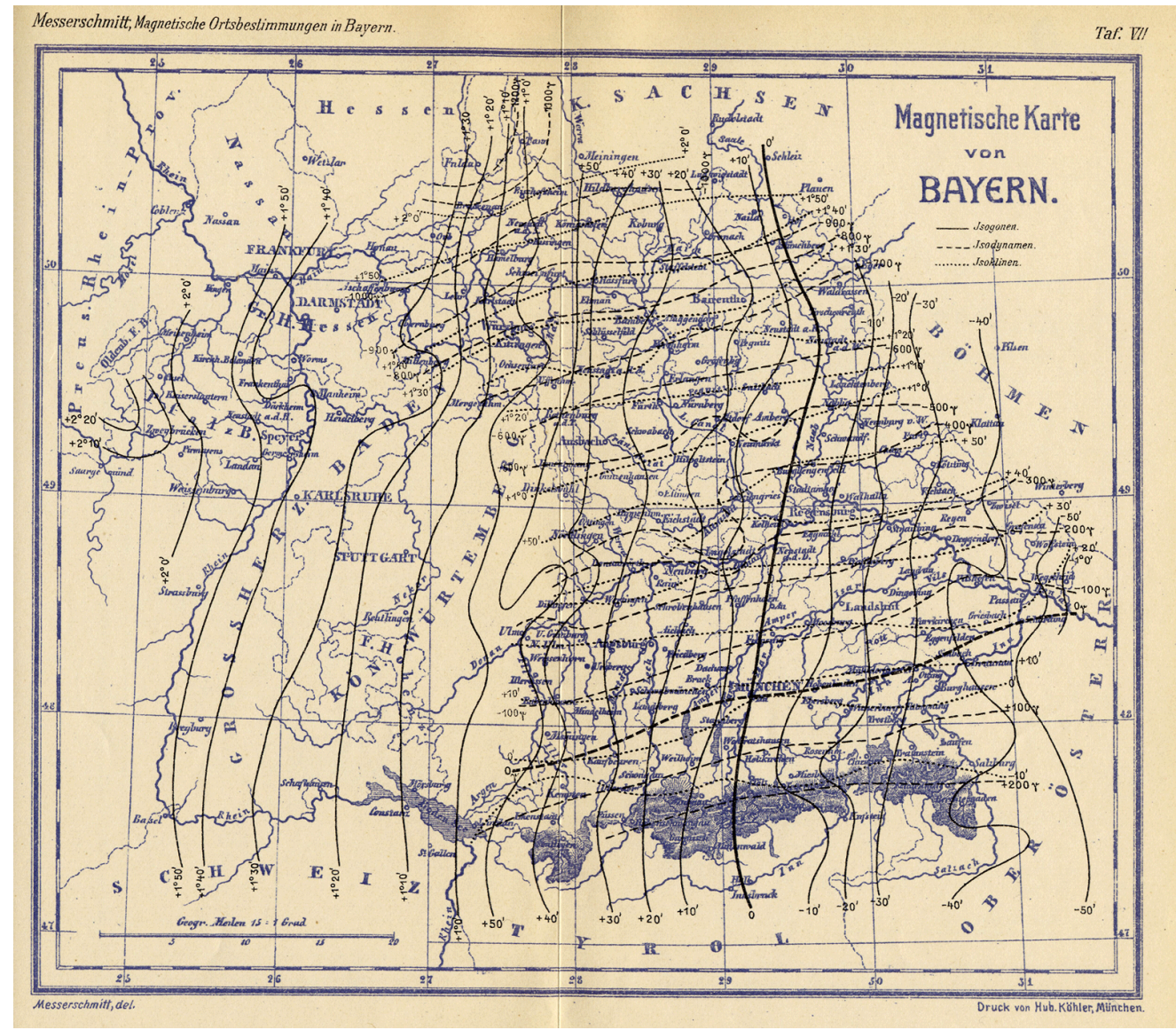

Figure 11. Geomagnetic map for Bavaria including the territories in the Palatinate to the west of the river Rhine. The measurements were made by Messerschmitt between 1903 and 1906 using a nonmagnetic TESDORPF theodolite. The data have been reduced to the mean values in Munich in 1905 (Messerschmitt, 1906). Reference data for Munich in 1905 are $D=-10^{\circ} 07.3^{\prime} \mathrm{E} ; I=63^{\circ} 10.5^{\prime}$; and $H=20635 \mathrm{nT}$. The map shows isolines of $D$ (full lines), $H$ (dashed lines) and $I$ (dotted lines). Differences between the isolines are $10^{\prime}$ for $D$ and $I, 100 \mathrm{nT}$ for $H$.

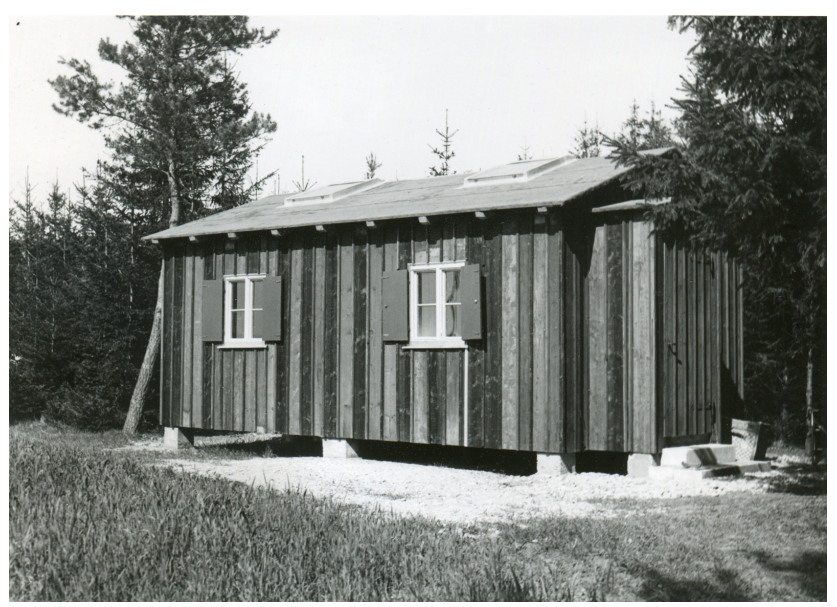

Figure 12. Simple wooden hut (Maisacher Hütte) which served as a storage room for the equipment after 1923 and later also as a provisional measuring site for the observatory in Maisach.
However, despite the considerable improvement in the quality of the geomagnetic measurements, Burmeister wished to have a much better observatory, one which would meet all international standards. The situation changed dramatically when it was decided by the government in Berlin that a small civilian airport near Maisach should be converted into a military airbase. In 1936 a new application was sent to the ministry in Munich, accompanied by numerous letters of support from various military, civil, and scientific authorities. Soon, a site near Fürstenfeldbruck was identified (Fig. 15). The new buildings were erected during 1938 (Plate 2a-g). For up-to-date pictures of the Variationshaus, the Absoluthaus and the Maisacher Hütte, see Plate $2 \mathrm{~h}-\mathrm{j}$. During that year the observatory was taken away from the Bavarian Academy of Sciences and transferred to the Chair of Astronomy at the University of Munich.

The measurements in the new observatory were resumed on 1 January 1939. Dr. Richard Bock and other colleagues from the Potsdam Observatory, which had to be transferred 


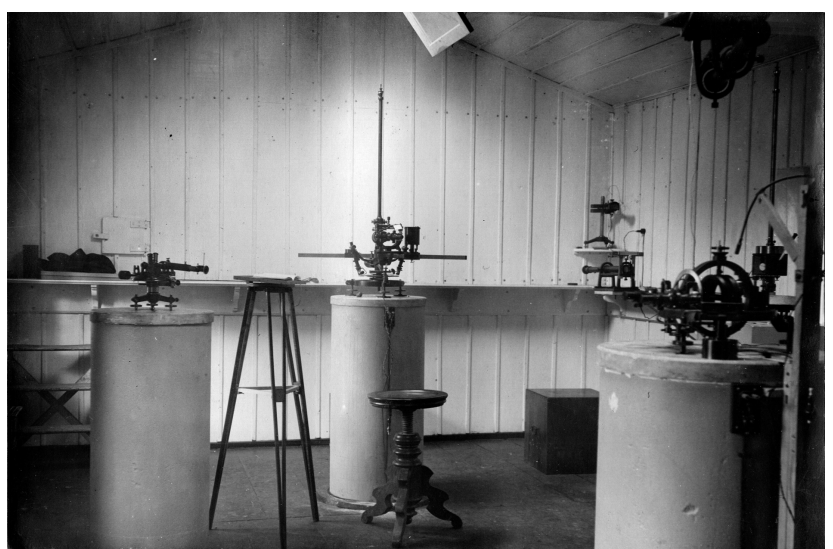

Figure 13. Interior of the Maisacher Hütte, where pillars for the instruments for absolute measurements were installed later.

to Niemegk in 1930, helped the colleagues in Munich to calibrate the instruments. Without their continual help and support, it would probably not have been possible to rebuild the observatory at a new site and to start with the measurements in such a short time.

In 1938 Dr. Walther Oberbauer (1905-1945, Plate 1j) was appointed as assistant of Burmeister. He had studied mathematics and astronomy and was a big help in the analysis of the geomagnetic data. He also helped to produce a declination map for Germany and eastern Europe in 1940. Unfortunately Oberbauer died in April 1945. While the seismic observatory in Bogenhausen ceased to exist in 1943 because the site was hit by various bombs during the Second World War, the Geomagnetic Observatory was not affected and continued its observations and measurements in May 1945 after only a short interruption. The military authorities in Bavaria had soon realized that geomagnetic measurements were necessary for science as well as for the regional monitoring of the state of the ionosphere and magnetosphere. In 1946 Lutz retired and in 1947 Dr. Kurt Burkhart (*1913, Plate 1k), who had studied meteorology at the University of Frankfurt, was appointed as Lutz' successor. He also continued Lutz' work on atmospheric electricity in Fürstenfeldbruck. For more details of these kinds of measurements, see Wienert (1966) and Korschunow (1966).

\section{History of the Geomagnetic Observatory after 1948}

In 1948 a chair for applied geophysics was established at the University of Munich and Prof. Dr. Hermann Reich (18911976, Plate 11) was appointed. One year later the geomagnetic observatory in Fürstenfeldbruck was transferred from the Chair of Astronomy to the Chair of Applied Geophysics and Prof. Reich also became director of the observatory. Friedrich Burmeister (Plate 1m) retired in 1957. He had been in charge of the observatory for 38 years between 1919 and

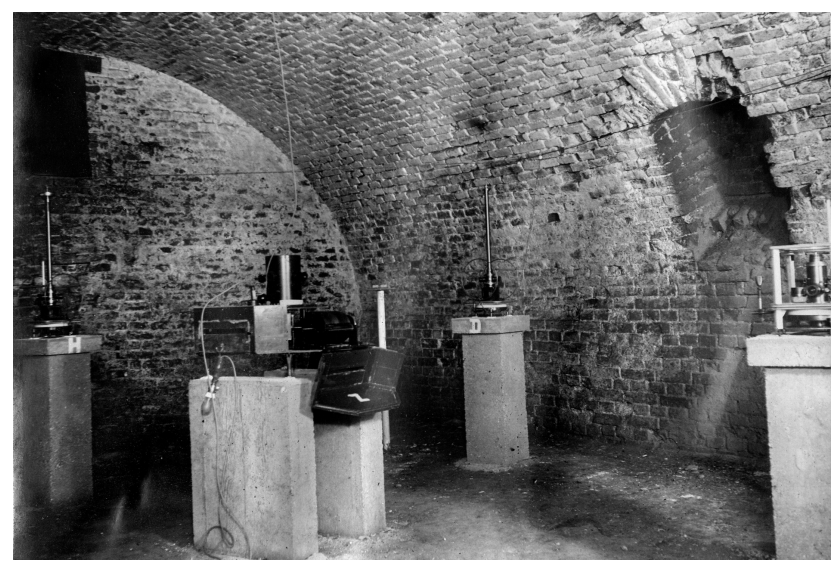

Figure 14. Basement of the brewery in Maisach called "Sommerkeller". Pillars with the instruments for the measurement of temporal variations of the field.

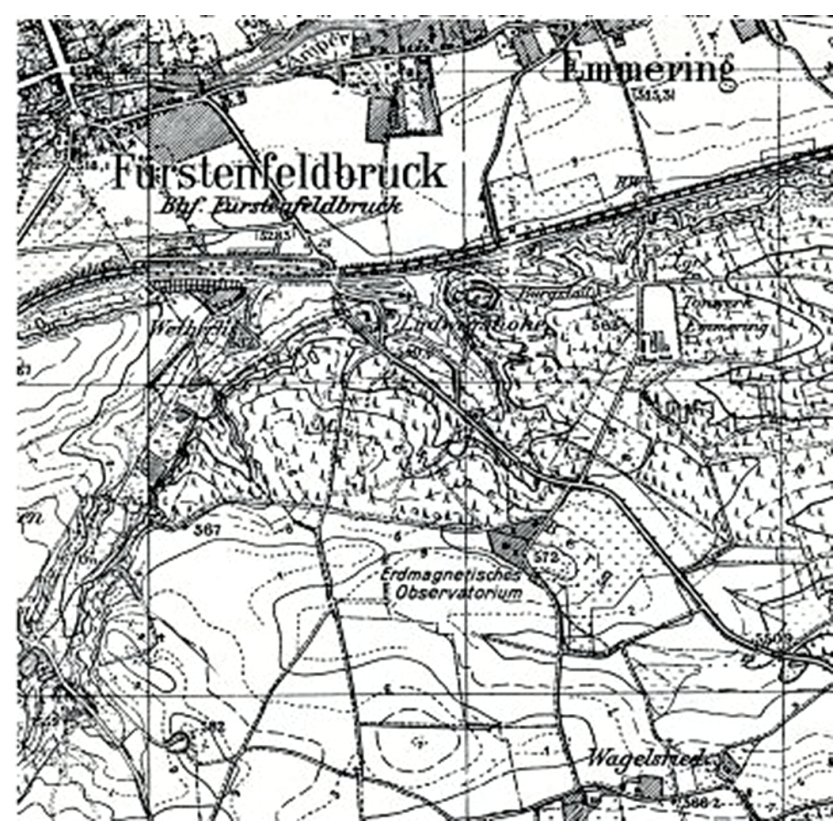

Figure 15. Map of the region south of Fürstenfeldbruck with the area of the observatory (Erdmagnetisches Observatorium).

1957. It was he who had succeeded in finding its new location. Without his talents and energy this would not have been possible. Dr. Kurt Burkhart left the observatory in 1958 to work for a meteorological institution of the new German Air Force in Memmingen in Bavaria.

In 1957 Prof. Dr. Gustav Angenheister (1917-1991, Plate 1n) from Göttingen followed Hermann Reich in the Chair of Applied Geophysics and as director of the observatory. Burmeister was succeeded by Dr. Karl Wienert (19131992, Plate 1o). He was an internationally known specialist in geomagnetism who had served IAGA to set up new geomagnetic observatories in Pakistan and Egypt during the 
(a)

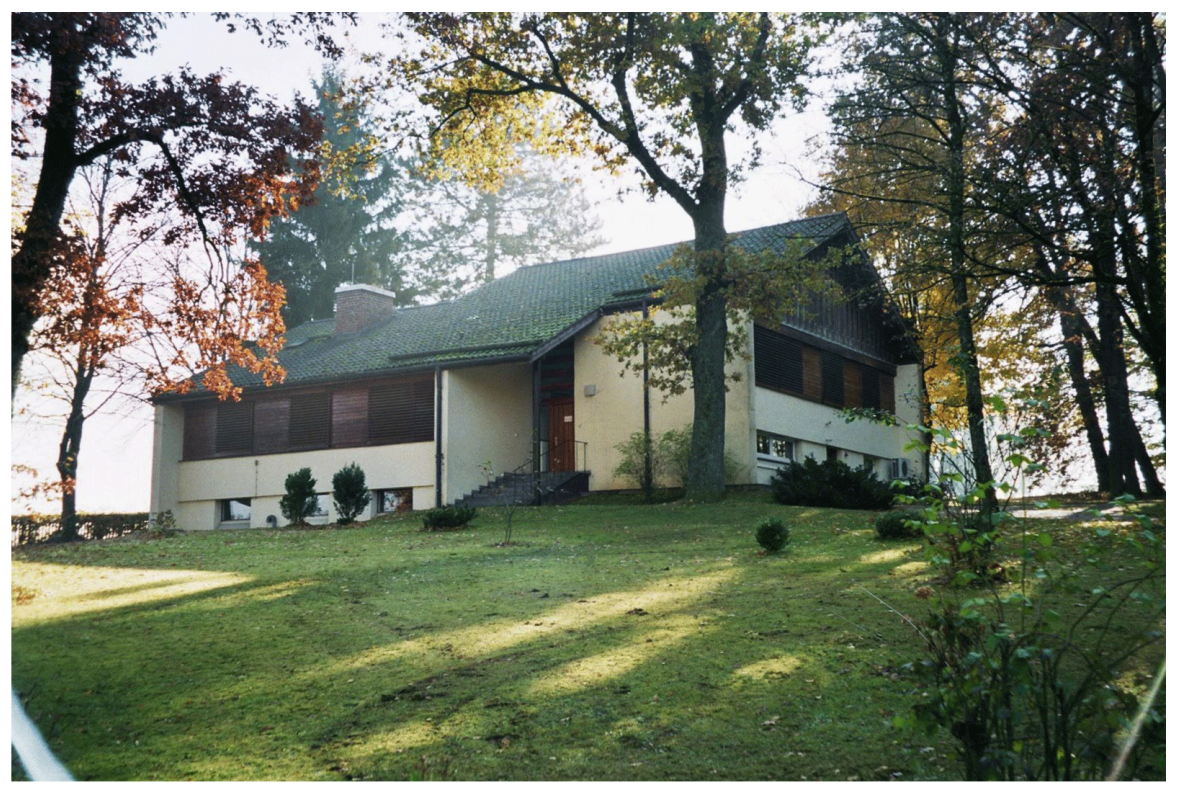

(b)

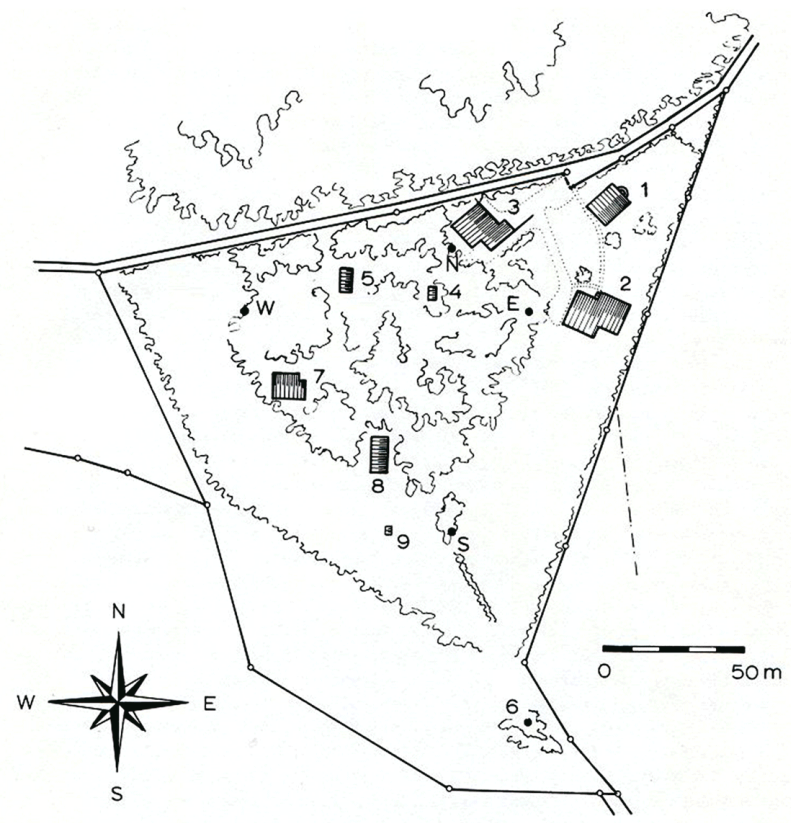

Figure 16. (a) The new main building of the observatory, finished in 1963. (b) Actual plan of the observatory. (1) Main building from 1938. (2) Main building from 1963. (3) Garage and archive. (5) Maisacher Hütte. (6) Bunker for the seismometers. (7) Variationshaus. (8) Absoluthaus. (9) Chronograph house. E-W and N-S: end points of lines to measure potential differences.

1950s. Angenheister was able to raise funds for modern equipment and for a new main building of the observatory which was finished in 1963 (Fig. 16a). Figure 16b shows a modern plan of all buildings of the observatory site.

In the early 1960s Wienert started to develop a proton magnetometer of his own design and hereby improved the quality of the permanently measured geomagnetic parame- ters considerably in the following years. It was possible to bring the observatory back to international standards. In 1958 Dr. Alex Korschunow (1918-2005, Plate 1p) was appointed to the vacant position which was formerly held by Kurt Burkhart. He continued the work of Burkhart, in addition focussing on the observation of short period geomagnetic temporal variations, mainly pulsations. For this he used induc- 
(a)

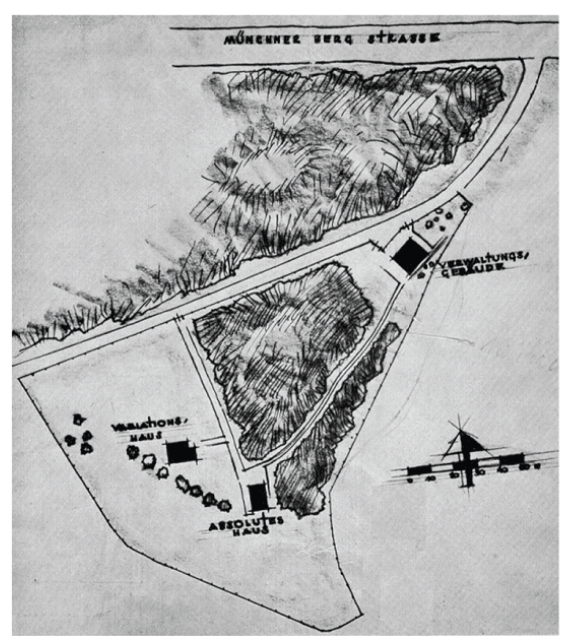

(c)

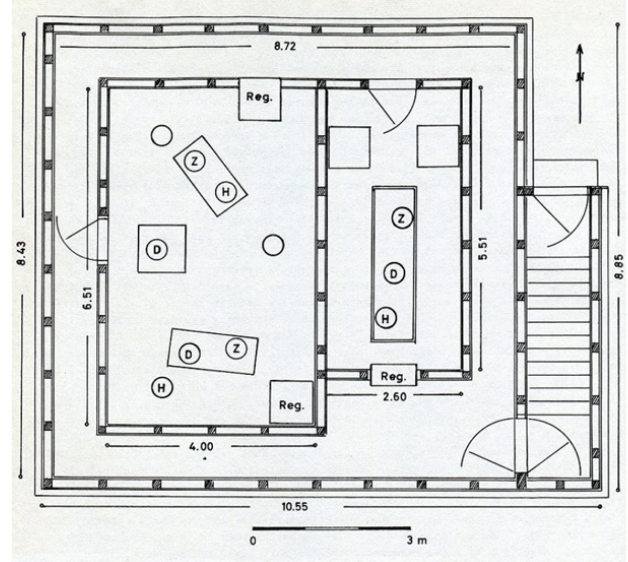

(b)

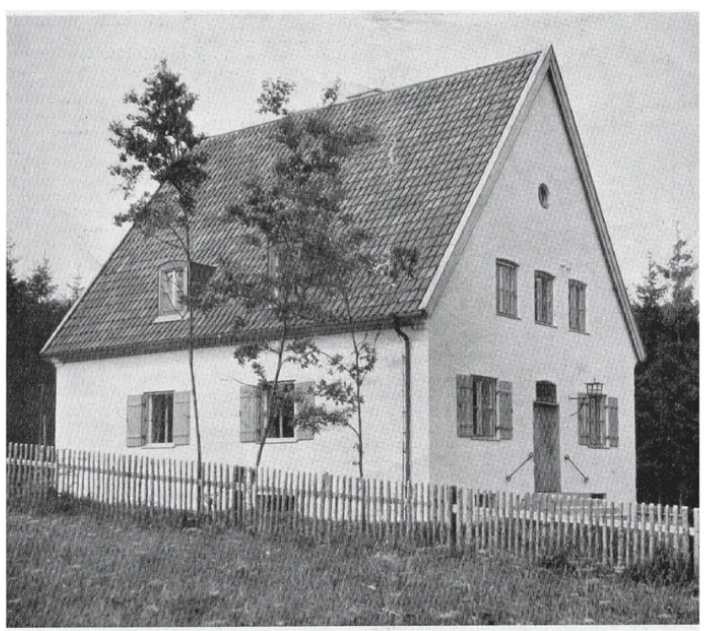

(d)

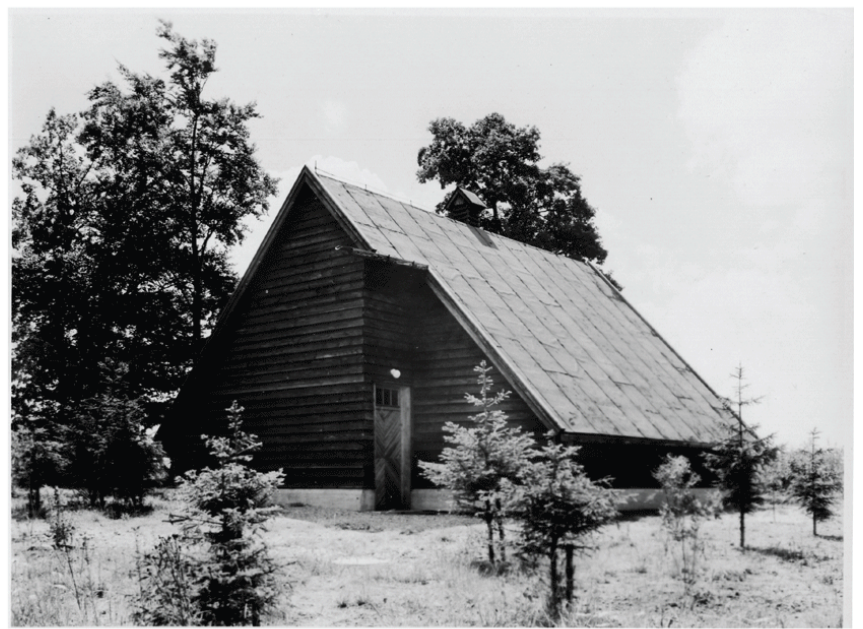

(e)

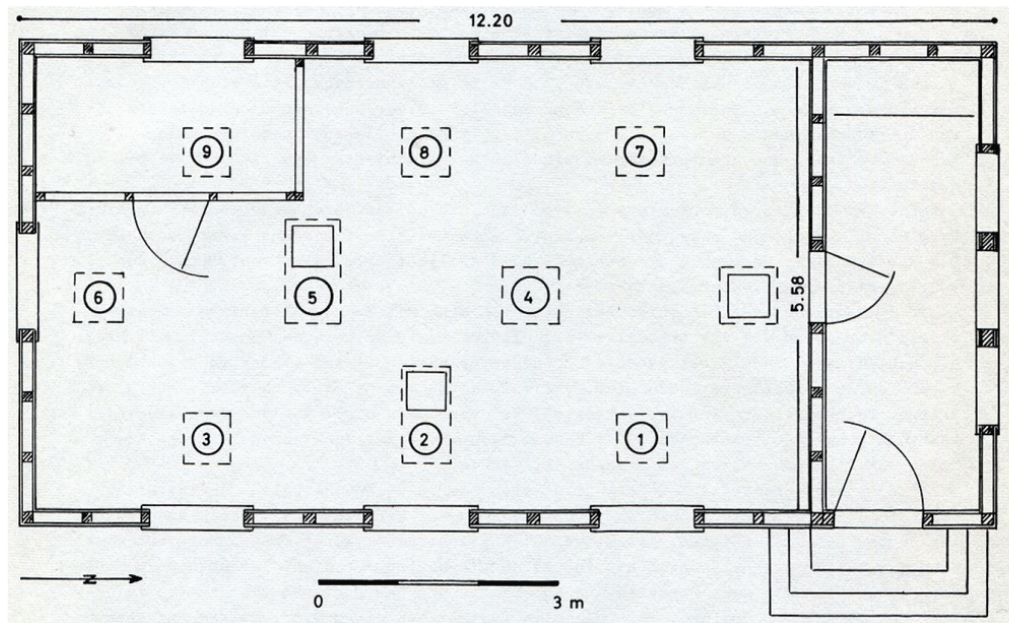

Plate 2. 
(f)

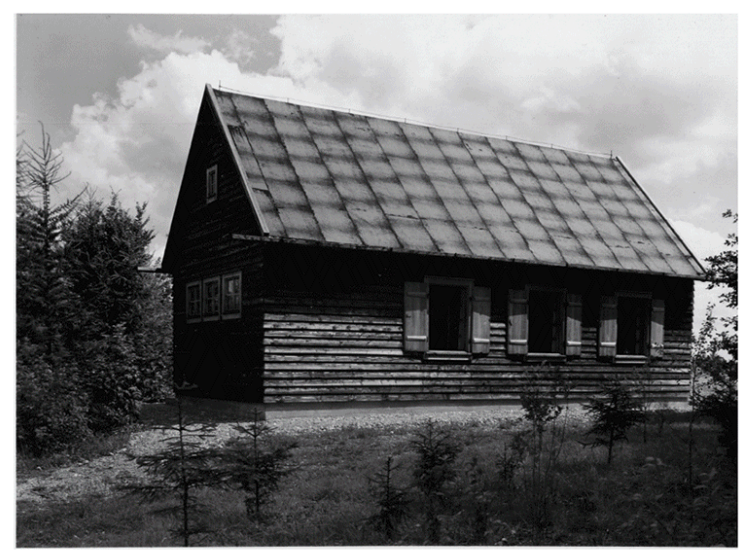

(h)

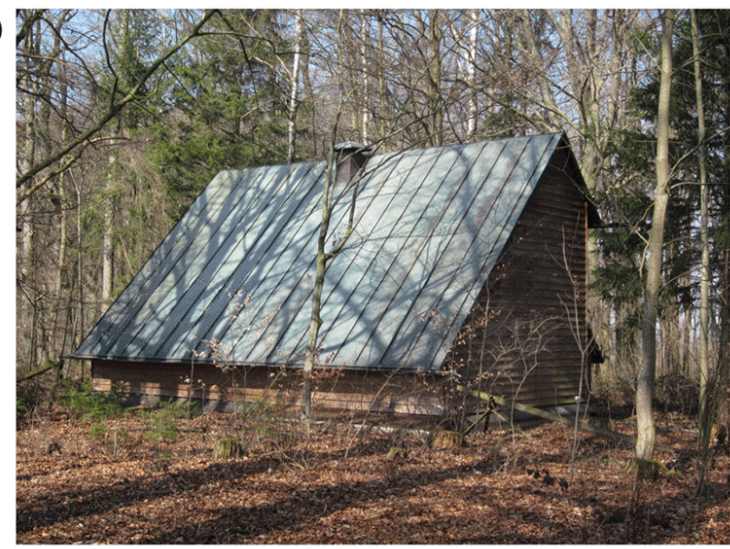

(g)

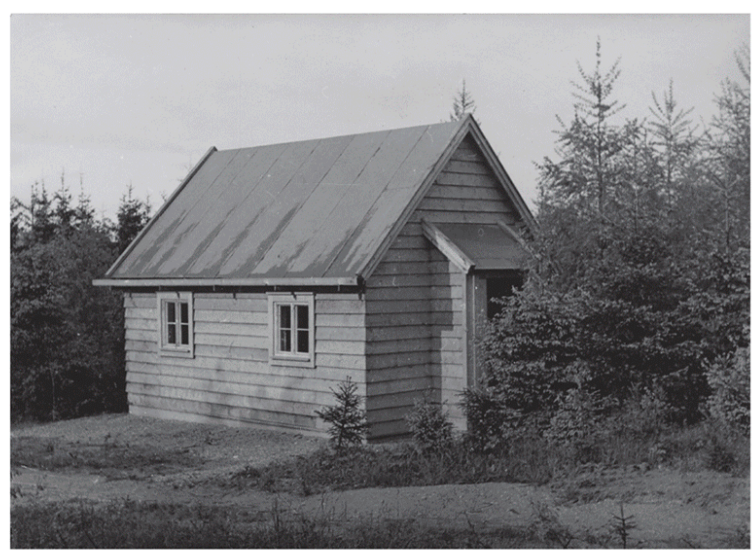

(i)

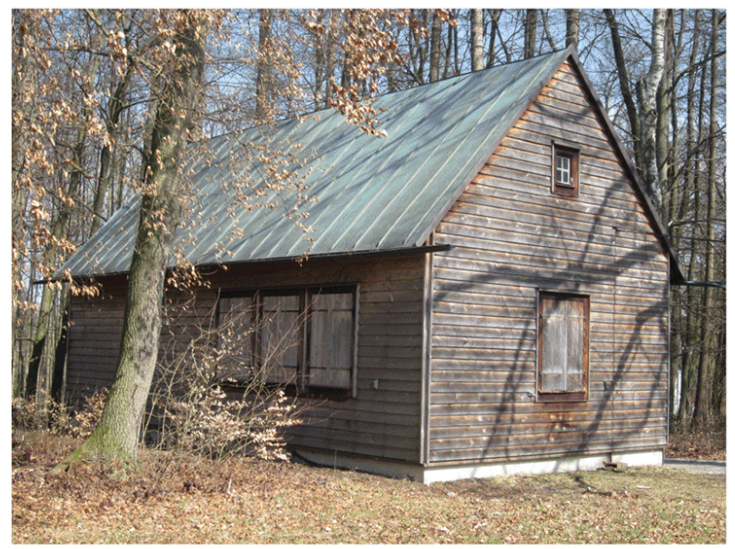

(j)

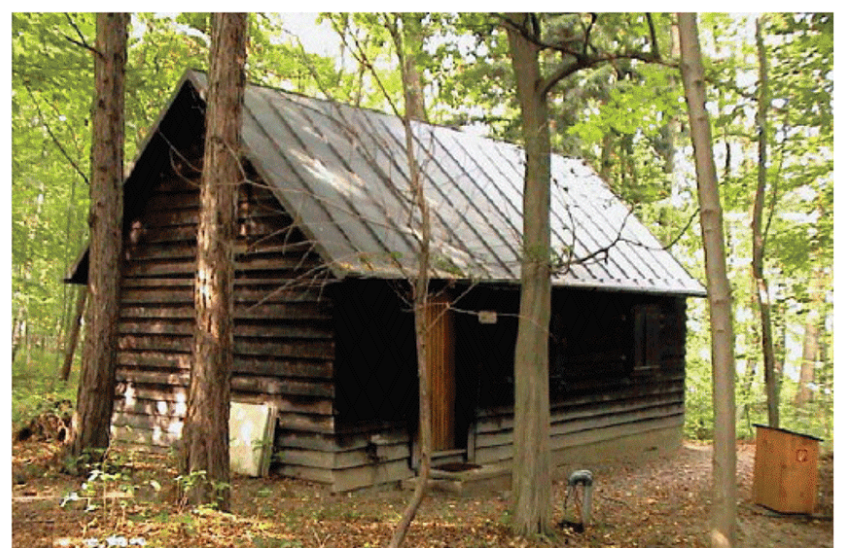

Plate 2. Plans and pictures of the new buildings in Fürstenfeldbruck. (a) Original plan of 1937 for the new observatory site near Fürstenfeldbruck consisting of an administration building (Verwaltungsgebäude), a house for the observations of temporal variations (Variationshaus) and a house for absolute measurements (Absoluthaus). (b) Administration building. Picture from 1939. (c) Plan of the interior of the house for the measurement of the variations (Variationshaus). It was planned to install two independent systems for the recording of the temporal variations of $D, H$ and $I$. (d) View of the Variationshaus from outside. Picture from 1939. (e) Plan of the interior of the house for absolute measurements (Absoluthaus) showing the positions of the pillars for the instruments. (f) View of the Absoluthaus from outside. Picture from 1939. (g) Renovated Maisacher Hütte with a new roof. Picture from 1939. (h) View of the Variationshaus from outside. Picture from 2015. (i) View of the Absoluthaus from outside. Picture from 2015. (j) View of the Maisacher Hütte with a new entrance door. Picture from 2014. 
(a)

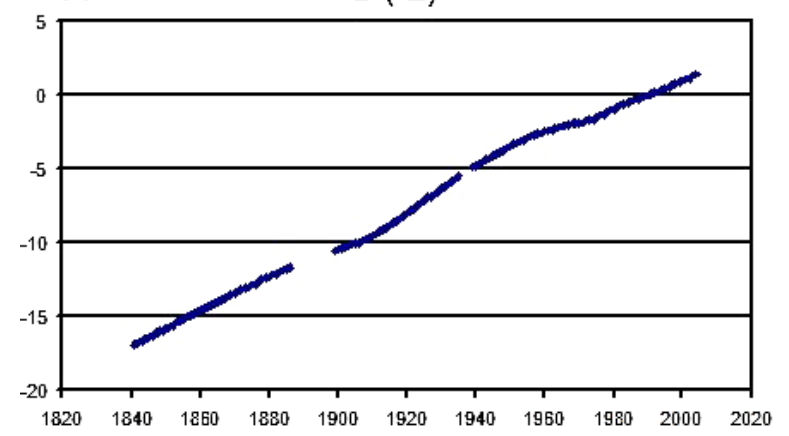

(b)

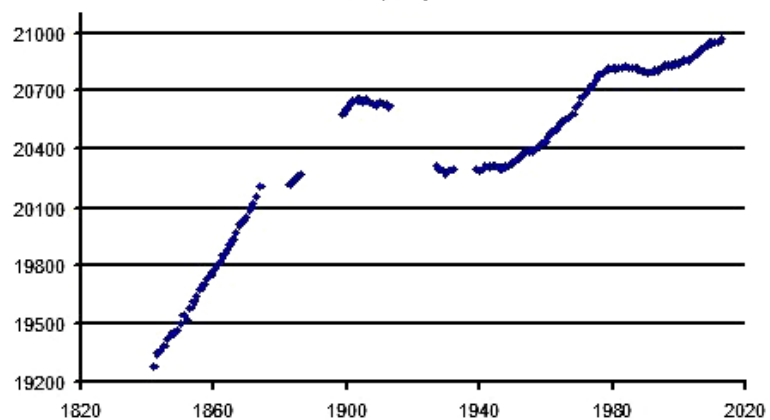

(c)

$I\left(^{\circ}\right)$

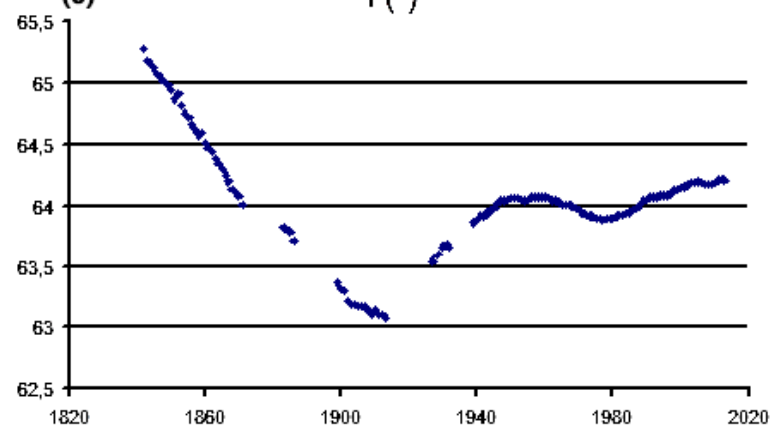

Figure 17. Variations of the geomagnetic field parameters between 1840 and 2014. (a) Declination $D$. (b) Horizontal intensity $H$. (c) Inclination $I$. The plots also reveal the time intervals when measurements were interrupted or when their quality was not adequate.

tion magnetometers (coil systems) and recorded the data in the Maisacher Hütte. Korschunow retired in 1980.

Dr. Karl Wienert retired in 1978 and Dr. Martin Beblo (Plate 1q) succeeded him as the scientist responsible for geomagnetism. It was he who introduced computers into the routine work of the observatory. Since this time Fürstenfeldbruck has been part of INTERMAGNET, a group of now about 120 geomagnetic observatories providing data with the highest quality. In 1985 Prof. Dr. Heinrich Soffel (Plate 1r) was appointed to the Chair of Applied Geophysics and as director of the observatory. Like his predecessor he was able to raise money both for the modernization of the equipment of the Geophysical Institute and of the observatory. After his retirement in 2002 Prof. Dr. Hans-Peter Bunge (Plate 1s) was appointed to the Chair of Geophysics and as director of the observatory, and the equipment was modernized again. Unfortunately the position of the geomagnetist, which was held by Dr. Beblo from 1978 to 2002, was eliminated by the university. Since 2006 Prof. Dr. Stuart Gilder (Plate 1t) has been the only permanent scientist responsible for the geomagnetism branch of the observatory and of the institute in Munich at the university. Nevertheless, the observatory has continued its high-quality observation and recording of the geomagnetic field. Martin Feller (Plate 1u), a technician, is at present responsible for the routine measurements and maintenance of the equipment. During the long history of the ob- servatory, different instruments have been used. Details can be taken from the Appendix.

\section{Final remarks}

The Munich-Maisach-Fürstenfeldbruck Geomagnetic Observatory has supported measurement of the geomagnetic field since 1 August 1840. It has one of the longest records of the geomagnetic field. The data between 1840 and 2014 are shown in Fig. 17a-c. Due to circumstances explained in this paper, several interruptions of the measurements occurred. Nevertheless, some of the data, especially declination, show a remarkable continuity of secular variation during the last 175 years; the data for horizontal intensity and inclination seem to be of lower quality and reliability during those times when the very existence of the observatory was at risk. We hope that such times never return. 
Appendix A: Instruments used in the observatory since 1836 and preservation of the data

When Lamont and Steinheil began measurement of declination $D$ and horizontal intensity $H$ in the basement of the Astronomical Observatory in 1836, they used instruments constructed by Gauss and Meyerstein in Göttingen. They consisted of heavy magnets with a bifilar suspension. From 1837 onward Lamont tried to develop an instrument to measure declination $D$ and horizontal intensity $H$ with monofilar suspension of the magnet. Nevertheless, he started the regular geomagnetic measurements on 1 August 1840 using Gauss's instruments. Immediately afterwards he experimented with magnetometers with small magnets weighing only some grams and with bifilar suspension. In the early 1840s he developed a nonmagnetic theodolite as the main instrument for the observatory for the measurement of $D$ and $H$. It was much smaller than Gauss's equipment and easier to handle. For the inclination he used a dip needle as well as an instrument invented by H. Lloyd (1800-1881) which also allowed the observation of the temporal variations of $I$. The equipment in the observatory in Munich for the measurement of $D, H$ and $I$ was used without major changes until the mid-1880s. Some of Lamont's early instruments are now in the Deutsches Museum in Munich. The collection includes a complete copy of his nonmagnetic theodolite for measuring the geomagnetic parameters in the field (Reisetheodolit), which has already been described earlier in this paper. It can be regarded as the standard instrument for magnetic observations all over the world during the nineteenth century. After Lamont's death in 1879 his technician C. Feldkirchner continued the measurements until he died in 1886. In this year the Geomagnetic Observatory in Munich ceased to exist.

In 1898 completely new instruments were acquired by F. von Schwarz for the new laboratories for geomagnetism. They replaced Lamont's outdated and worn-out equipment. A new nonmagnetic theodolite for the measurement of $D$ and $H$ (BAMBERG no. 1661) was installed. An instrument for the measurement of the inclination equipped with four needles came from the same company (BAMBERG no. 6817). In addition to that, an earth inductor produced by EDELMANN served for the measurement of the total intensity as well as for the determination of $D$ and $I$. The data were now recorded on photographic paper. This equipment served in the observatory for many years.

When it became evident that the measurements in Bogenhausen had to be given up because of too much magnetic noise, absolute and later also time-variable geomagnetic data were determined in Maisach near Fürstenfeldbruck after the mid-1920s. The instruments acquired in 1897/98 were used for that purpose. However, they had to be technically revised and modernized to some extent. A new theodolite (SCHULZE no. 65) besides instrument BAMBERG no. 1661 was installed. This was the instrumentation in Maisach from 1923 to 1939. Figures and plans for the buildings of the new observatory in Fürstenfeldbruck from 1939 onward and their present condition in 2015 are shown in Plate 2. For details, see captions.

After 1939 the recording of the temporal variations of the field in the Variationshaus (see Plate $2 \mathrm{c}$ and d) took place using three new SCHULZE instruments. The EDELMANN system, acquired in 1897, served as spare equipment (see Plate $2 \mathrm{c}$ and d). For the absolute measurements in the "Absoluthaus" (see Plate 2e and f), the SCHULZE no. 65 theodolite for the measurement of $D$ and $H$ rested on pillar no. 4. From this place the church spire of the nearby village of Alling at a distance of about $3 \mathrm{~km}$ as the reference direction could be seen through an open window on the southeastern part of the building. An earth inductor (SCHULZE no. 550) rested on pillar no. 5.

In order to control the baseline stability of the instruments for the absolute measurements, an agreement was made between the Rude Skov (Denmark), Wien-Kobenzl (Austria), and Niemegk, Wingst and Fürstenfeldbruck (Germany) observatories to compare the data at 02:00 a.m. Greenwich time on 10 selected quiet days each month. This led to a considerable improvement of the declination measurements with the SCHULZE no. 65 theodolite. In 1959 the observatory bought the BMZ no. 237 instrument to improve the quality of the measurements of the vertical intensity.

In 1962 a proton precession magnetometer was developed by Dr. Karl Wienert in the workshop of the observatory. Its quality and reliability were checked using a ELSEC no. 128 proton magnetometer and it became the standard instrument of the observatory for absolute measurements until 1980. After 1970 only proton magnetometers (WIENERT until 1985, ELSEC type 770 until 1987, EDA PPM 105 up to today) were used in combination with Helmholtz coils for the determination of components $\mathrm{F}$ and $\mathrm{Z}$. $\mathrm{H}$ was computed from these data using the Nelson method (Hurwitz and Nelson, 1960).

In 1975 the observatory started to develop a fluxgate system for the recording of the $X, Y$ and $Z$ components of the field according to the IAGA format (digital values each minute). Unfortunately, the stability of the fluxgates of those days did not meet the requirements of an observatory. With the invention of stable fluxgate sensors and the introduction of computers into the routine work of the observatory, it became possible in the mid-1980s to give up some of the traditional instruments for the measurement of temporal variations with the classical method of suspended magnets and photographic recording. For the digital recording of the geomagnetic variations, the SCHULZE system (with photographic recording, acquired in 1939 and modified by LEHNER in 1964) was replaced in 1982 by a digital recording system. This new technique has been described by Beblo (1984, 1990) and Beblo and Feller (1991). In 1993 the measurement of the variations was modernized again by a new three-component fluxgate sensor with a gimbal suspension from MAGSON (Berlin). It was replaced in 1997 by 
a three-component fluxgate system with a gimbal suspension from the Danish Meteorological Institute (DMI, RASMUSSEN system).

The declination and inclination could be determined absolutely after 1985 with the nonmagnetic THEO 010A theodolite from Zeiss/Jena combined with fluxgate magnetometers from BARTINGTON as zero instruments. For the absolute measurements, a second nonmagnetic THEO 020A theodolite (Zeiss/Jena) in combination with a BARTINGTON fluxgate sensor was acquired in 1993. In 1996 the absolute measurements with the old SCHULZE no. 65 theodolite were discontinued and the observatory got an additional THEO 020B theodolite (Zeiss/Jena) with a MAGSON fluxgate sensor. In 1997 and 2000 two new Overhauser proton magnetometers of type GEM GSM90 could be acquired, followed by an STL24 data logger from the SYSTEMTECHNIK company. Finally, in 2003, the optical registration of variations using the SCHULZE system came to an end and in the same year the observatory obtained another nonmagnetic THEO 020A theodolite (Zeiss/Jena) combined with a fluxgate sen- sor from BARTINGTON. Several spare systems also exist in case some of the instruments fail, for instance as a result of lightning damage. At the present time the observatory in Fürstenfeldbruck is always able to fulfil all specifications required for the members of INTERMAGNET.

The data obtained in the observatory in the form of annual means since 1840 have been documented for the period 1840 to 1954 by Burmeister (1941, 1938-1953). In later times they were published annually in a special series of the University of Munich (Münchner Universitätsschriften, Serie A) by Wienert (1959, 1960-1978), Beblo (1979-2003) and Matzka (2004). All data since 1840 are also available in digital form on the home page of the observatory under the address www.geophysik.uni-muenchen.de. 
Acknowledgements. The help of M. Beblo and M. Feller for critically reading the manuscript and providing details of the instruments of the observatory is gratefully acknowledged. Many thanks are also due to two reviewers (V. Courtillot and R. Holme) for their constructive comments and the improvement of the text.

Edited by: D. Cole

Reviewed by: K. H. Glassmeier, V. Courtillot, and R. Holme

\section{References}

Angenheister, G.: Die Beobachtungen des Erdstromes von Johann von Lamont in den Jahren 1856-1862, Münchner Geophys. Mitt., Münchner Univers. Schriften, ISSN 0931-2145, 5, 25-30, 1991.

Barraclough, D. R., Clark, T. D. G., Cowley, S. W. H., Gubbins, D., Hibberd, F. H., Hide, R., Kerridge, D. J., Lowes, F. J., Malin, S. R. C., Murthy, T., Rishbeth, H., Runcorn, S. K., Soffel, H. C., Stewart, D. N., Stuart, W. F., Whaler, K. A., and Winch, D. E.: 150 years of magnetic observatories: recent researches on world data, Surveys in Geophys., 13, 47-88, 1992.

Beblo, M.: Die neuen Magnetometer des Observatoriums Fürstenfeldbruck. In: Protokoll Elektromagnetische Tiefenforschung, Grafrath, Unpublished reports, Archive of the Observatory, 1984.

Beblo, M.: A digital magnetometer system using classical variometers and opto-electronic converters, Phys. Earth Planet. Int., 59, 82-88, 1990.

Beblo, M.: 150 years Earthmagnetic Observatories MünchenMaisach-Fürstenfeldbruck, Münchner Geophys. Mitt., Münchner Univers. Schriften, ISSN 0931-2145, 5, 11-18, 1991.

Beblo, M.: Ergebnisse der erdmagnetischen Beobachtungen in den Jahren 1978 bis 2002, Münchner Univers. Schriften, ISSN 09312145, Serie A, Nr. 21 bis 45, München, 1979-2003.

Beblo, M. and Feller, M.: Digital recording oft the Earth's magnetic Field at the Geophysical Observatory Fürstenfeldbruck, Münchner Geophys. Mitt., Münchner Univers. Schriften, ISSN 09312145, 5, 109-118, 1991.

Burmeister, F.: Die Erdmagnetischen Observatorien München, Maisach, Fürstenfeldbruck in ihrer Entwicklung von 1840 bis 1940, Veröffentlichungen der Erdphysikalischen Warte bei der Sternwarte, Heft 7, München, Unpublished reports, Archive of the Observatory, 1941

Burmeister, F.: Johann von Lamont und das Erdmagnetische Observatorium in München. Vortrag bei der Feier des 110-jährigen Bestehens des Observatoriums, Unpublished reports, Archive of the Observatory, 1950

Burmeister, F.: Ergebnisse der Magnetischen Beobachtungen des Observatoriums Fürstenfeldbruck, Unpublished reports, Archive of the Observatory, 1938-1953.

Gauss, C. F.: Intensitas vis magneticae terrestris ad mensuram absolutam revocata, Sumtibus Dieterichianis, Göttingen, 1833.

Haak, V.: Two theses of Johann von Lamont - 150 Years later, Münchner Geophys. Mitt., Münchner Univers. Schriften, ISSN 0931-2145, 5, 31-42, 1991.

Haak, V.: Extended abstract 22nd EM Induction Workshop Weimar, Germany, edited by: Ritter, O., Geoforschungszentrum Potsdam, Germany, 24-30 August 2014.

Häfner, R. and Soffel, H.: Johann von Lamont - Leben und Werk, Festschrift zu seinem 200. Geburtstag, Bayerische Akademie der Wissenschaften, Universitätssternwarte und Geophysikalisches Observatorium der Universität München, München, Unpublished reports, Archive of the Observatory, 2006.

Hurwitz, L. and Nelson, J. H.: Proton Vector Magnetometer, J. Geophys. Res., 65, 1759-1765, 1960.

Kohlrausch, F.: Diskussion über die Frage der Störungen wissenschaftlicher Institute durch elektrische Bahnen, Elektrotechnische Zeitschrift (Centralblatt für Elektrotechnik), Volume 27 and 28, 1895.

Korschunow, A.: Zur Geschichte besonderer geophysikalischer Beobachtungen an der Sternwarte in München und im Geophysikalischen Observatorium zu Fürstenfeldbruck, die über den Rahmen des normalen erdmagnetischen Beobachtungsprogramms hinausgehen, in: 125 Jahre erdmagnetische Beobachtungen in München, Maisach und Fürstenfeldbruck. edited by: Wienert, K., in: Zum 125-jährigen Bestehen der Observatorien München-Maisach-Fürstenfeldbruck, Festschrift des Observatoriums, München, Unpublished reports, Archive of the Observatory, 1966.

Lamont, J.: Über das magnetische Observatorium in München, München, 1841.

Lamont, J.: Bestimmung der Horizontalintensität des Erdmagnetismus nach absolutem Maße, München, 1842.

Lamont, J.: Resultate des magnetischen Observatoriums in München während der dreijährigen Periode 1843-1844-1845, München, 1846.

Lamont, J.: Magnetische Ortsbestimmungen ausgeführt an verschiedenen Punkten des Königreichs Bayern und an einigen auswärtigen Stationen, 1. Teil. München, 1854a.

Lamont, J.: Magnetische Karten von Deutschland und Bayern und den neuen bayerischen und österreichischen Messungen, unter Benutzung einiger älterer Bestimmungen, 1. Teil, München, $1854 b$.

Lamont, J.: Untersuchungen über die Richtung und Stärke des Erdmagnetismus an verschiedenen Punkten des südwestlichen Europa im allerhöchsten Auftrage seiner Majestät des Königs Maximilian II. von Bayern ausgeführt, München, 1858.

Lamont, J.: Untersuchungen über die Richtung und Stärke des Erdmagnetismus in Norddeutschland, Belgien, Holland, Dänemark im Sommer des Jahres 1858 ausgeführt und auf öffentliche Kosten herausgegeben, München, 1859.

Lamont, J.: Der Erdstrom und der Zusammenhang desselben mit dem Magnetismus der Erde. Leipzig, Leopold Voss, 1862.

Matzka, J.: Ergebnisse der erdmagnetischen Beobachtungen im Jahre 2003, Münchner Univers. Schriften, ISSN 0931-2145, Serie A, Nr. 46, München, 2004.

Messerschmitt, J. B.: Magnetische Ortsbestimmungen in Bayern. Sitzungsbericht der Mathem.-Phys. Klasse der Bayerischen Akademie der Wissenschaften, München, Bd. 36, Heft 3, 545580, 1906.

Past, F.: Johann Georg von Soldner (1776-1833) und seine Zeit, Veröffentlichungen der Bayerischen Kommission für Internationale Erdmessung der Bayerischen Akademie der Wissenschaften, Astronomisch-Geodätische Arbeiten, Heft Nr. 62 , 1-23, ISSN 0340-7691, München, 2005.

Schröder, W., Wiederkehr, K.-H., and Schlegel, K.: Georg von Neumayer and geomagnetic research, Hist. Geo Space. Sci., 1, 7787, doi:10.5194/hgss-1-77-2010, 2010. 
Soffel, H.: Johann von Lamont (1805-1879): A pioneer in geomagnetism, The IRM Quarterly, Winter 2004-2005, p. 14, 1 and 8$11,2005 \mathrm{a}$.

Soffel, H.: Johann von Lamont (1805-1879), ein Pionier des Erdmagnetismus, Akademie Aktuell, Zeitschrift der Bayerischen Akademie der Wissenschaften, Ausgabe 02/2005, 30-35, ISSN 1435-753X, 2005b.

Soffel, H.: Johann von Lamont (1805-1879), ein Pionier bei der Erforschung des Erdmagnetfeldes, Mitt. Deutsche Geophys. Ges., 4/2005, 13-16, ISSN 0934-6554, 2005c.

Soffel, H.: Johann von Lamont (1805-1879) - Lebensweg und wissenschaftliche Leistungen unter besonderer Berücksichtigung seiner Arbeiten zur Erforschung des Erdmagnetfeldes, Veröffentlichungen der Bayerischen Kommission für Internationale Erdmessung der Bayerischen Akademie der Wissenschaften. Astronomisch-Geodätische Arbeiten, Heft Nr. 62, 1-18, ISSN 0340-7691, München, 2005d.

Soffel, H.: Johann von Lamont - A Pioneer in Geomagnetism, EOS, 87 , p. $247,2006$.
Soffel, H.: Johann von Lamont (1805-1879) - ein Pionier des Erdmagnetismus, Acta Historica Leopoldina, 55, 91-114, 2010.

Soffel, H. and Häfner, R.: Johann von Lamont (1805-1879), in: Denker, Forscher und Entdecker, Eine Geschichte der Bayerischen Akademie der Wissenschaften in historischen Portraits, edited by: Willoweit, D., Beck-Verlag München, 106-119, 2009.

Wienert, K.: Ergebnisse der erdmagnetischen Beobachtungen in den Jahren 1954-1958, Münchner Univers. Schriften, ISSN 0931-2145, Serie A, Nr. 1, München, 1959.

Wienert, K.: 125 Jahre erdmagnetische Beobachtungen in München, Maisach und Fürstenfeldbruck, in: Zum 125jährigen Bestehen der Observatorien München-MaisachFürstenfeldbruck, Festschrift des Observatoriums, München, Unpublished reports, Archive of the Observatory, Unpublished reports, Archive of the Observatory, 1966.

Wienert, K.: Ergebnisse der erdmagnetischen Beobachtungen in den Jahren 1959 bis 1977, Münchner Univers. Schriften, ISSN 0931-2145, Serie A, Nr. 2 bis 20, München, 1960-1978.

Wienert, K.: Where John Lamont spent the first 12 years of his life. Münchner Geophys. Mitt., Münchner Univers. Schriften, ISSN 0931-2145, 5, 19-24, 1991. 